\title{
The anthropogenic contribution to atmospheric black carbon concentrations in southern Africa: a WRF-Chem modeling study
}

\author{
F. Kuik ${ }^{1}$, A. Lauer ${ }^{1, \text { a }}$, J. P. Beukes ${ }^{2}$, P. G. Van Zyl², M. Josipovic ${ }^{2}$, V. Vakkari ${ }^{3}$, L. Laakso ${ }^{2,3}$, and G. T. Feig ${ }^{4}$ \\ ${ }^{1}$ Institute for Advanced Sustainability Studies (IASS) Potsdam, Germany \\ ${ }^{2}$ Unit for Environmental Sciences and Management, North-West University, \\ Potchefstroom, South Africa \\ ${ }^{3}$ Finnish Meteorological Institute, Helsinki, Finland \\ ${ }^{4}$ South African Weather Service, Pretoria, South Africa \\ ${ }^{a}$ now at: Deutsches Zentrum für Luft- und Raumfahrt (DLR), Institut für \\ Physik der Atmosphäre, Oberpfaffenhofen, Germany
}

Correspondence to: F. Kuik (friderike.kuik@iass-potsdam.de)

Received: 9 February 2015 - Published in Atmos. Chem. Phys. Discuss.: 10 March 2015

Revised: 25 June 2015 - Accepted: 15 July 2015 - Published: 12 August 2015

\begin{abstract}
South Africa has one of the largest industrialized economies in Africa. Emissions of air pollutants are particularly high in the Johannesburg-Pretoria metropolitan area, the Mpumalanga Highveld and the Vaal Triangle, resulting in local air pollution. This study presents and evaluates a setup for conducting modeling experiments over southern Africa with the Weather Research and Forecasting model including chemistry and aerosols (WRF-Chem), and analyzes the contribution of anthropogenic emissions to the total black carbon (BC) concentrations from September to December 2010.

The modeled BC concentrations are compared with measurements obtained at the Welgegund station situated ca. $100 \mathrm{~km}$ southwest of Johannesburg. An evaluation of WRF-Chem with observational data from ground-based measurement stations, radiosondes, and satellites shows that the meteorology is modeled mostly reasonably well, but precipitation amounts are widely overestimated and the onset of the wet season is modeled approximately 1 month too early in 2010. Modeled daily mean BC concentrations show a temporal correlation of 0.66 with measurements, but the total $\mathrm{BC}$ concentration is underestimated in the model by up to $50 \%$.

Sensitivity studies with anthropogenic emissions of BC and co-emitted species turned off show that anthropogenic sources can contribute up to $100 \%$ to BC concentrations in the industrialized and urban areas, and anthropogenic $\mathrm{BC}$ and co-emitted species together can contribute up to $60 \%$ to $\mathrm{PM}_{1}$ levels. Particularly the co-emitted species contribute signifi-
\end{abstract}

cantly to the aerosol optical depth (AOD). Furthermore, in areas of large-scale biomass-burning atmospheric heating rates are increased through absorption by BC up to an altitude of about $600 \mathrm{hPa}$.

\section{Introduction}

South Africa is one of Africa's largest economies and anthropogenic emissions of air pollutants from South Africa are of increasing concern. Due to South Africa's growing economy, fossil fuel consumption and energy demand are rising, with most of the electricity produced by coal-fired power plants (Lourens et al., 2011; Tiitta et al., 2014). Further contributions come from its large mining and metallurgical industry and domestic combustion, especially in informal settlements around towns (Venter et al., 2012). A large portion of South African anthropogenic emissions originate from the area around Johannesburg and Pretoria (Freiman and Piketh, 2003), a metropolitan area with a combined population of more than 10 million (Lourens et al., 2012), as well as the Mpumalanga Highveld and Vaal Triangle industrial areas that have both been declared pollution hotspots by the South African government (Lourens et al., 2011). Furthermore, large-scale biomass burning emissions contribute particularly during the dry winter season to air pollutant concentrations (e.g. Swap et al., 2003; Vakkari et al., 2014). The 
issue of air pollution in South Africa has been recognized and explored in several recent studies, mainly focusing on the measurement and characterization of both gaseous species and particulate matter (e.g. Laakso et al., 2008, 2012; Vakkari et al., 2011, 2013; Venter et al., 2012; Jaars et al., 2014; Tiitta et al., 2014; Beukes et al., 2013).

So far, regional modeling studies for southern Africa have mainly focused on the meteorology (e.g. Crétat et al., 2011). Solmon et al. (2006) modeled aerosols, including BC, with a domain covering Europe and large parts of Africa but did not include South Africa. They identify poorly developed emission inventories - especially for Africa - as one of the main deficiencies in modeling aerosol concentrations and note a lack of measurement data for model evaluation in Africa. The African Multidisciplinary Monsoon Analysis (AMMA) project was designed to address these gaps. Part of it was dedicated to comparing the performance of chemical transport and chemistry climate models, simulating the distribution of trace gases and aerosols over West Africa. The findings provide recommendations for future air chemistry modeling, emphasizing the need for improved anthropogenic emission inventories (Ruti et al., 2011). Laakso et al. (2013) simulated particle growth in South Africa with an offline global aerosol model. They found that the model does not reproduce the observed particle formation characteristics. This was attributed mainly to the emissions, with their monthly resolution not capturing the emissions' variability. Tummon et al. (2010) simulated the direct and semi-direct effects of biomass-burning aerosols in southern Africa, reporting regional changes induced by aerosols including surface cooling and heating of the atmosphere in higher altitudes, leading to enhanced tropospheric stability and a decreased height of the planetary boundary layer. The study does not explicitly assess anthropogenically emitted aerosols. To the authors' knowledge, no peer-reviewed study exists to date that is aimed at modeling anthropogenic black carbon (BC) with a regional model over southern Africa.

Black carbon is an important component of air pollution. It is a carbonaceous aerosol that is produced during the incomplete combustion of carbon-based fuels and materials. It is an aggregate of rapidly coagulating small carbon spheres, with a total size generally below $1 \mu \mathrm{m}$. Black carbon is characterized by its strong absorption of visible and near-infrared light and by its resistance to chemical transformation (Ogren and Charlson, 1983; Goldberg, 1985; Petzold et al., 2013).

In addition to the burning of biomass and industrial processes, in particular domestic cooking and heating, as well as the transport sector are major sources of BC in Africa (Bond et al., 2013). Fine particulate matter, and thus BC contained within, is associated with several adverse effects on human health. These include respiratory and cardiovascular morbidity, such as aggravation of asthma, respiratory symptoms and an increase in hospital admissions, as well as mortality from cardiovascular and respiratory diseases and from lung cancer (Janssen et al., 2012). Some empirical studies suggest that long-term exposure to $\mathrm{PM}_{2.5}$ containing a high $\mathrm{BC}$ fraction may have larger mortality effects than other $\mathrm{PM}_{2.5}$ mixtures (Smith et al., 2009).

The efficient absorption of solar radiation by $\mathrm{BC}$ makes these aerosols the most important absorber of visible light in the atmosphere. In addition to absorbing light while being suspended in the atmosphere, $\mathrm{BC}$ can reduce the amount of reflected sunlight when deposited on high albedo surfaces such as snow and ice. After carbon dioxide, emissions of $\mathrm{BC}$ are thought to make the second strongest contribution to current global warming (Ramanathan and Carmichael, 2008; Hodnebrog et al., 2014), though the exact climate forcing of BC is still under debate (e.g. Samset et al., 2014).

As BC has a short residence time in the atmosphere (few days) in comparison to $\mathrm{CO}_{2}$ (several years up to more than 100 years), emission reduction measures would rapidly lead to a decrease in concentrations, which would have beneficial effects for both air quality and climate (Ramanathan and Carmichael, 2008; Shindell et al., 2012). These properties lead to BC often being classified as a Short-Lived Climateforcing Pollutant (SLCP) (e.g. Schmale et al., 2014).

The metropolitan areas in South Africa are highly populated, and at the same time the population is highly vulnerable to air pollution and climate change because of their rather limited resources for adaptation. This is why an assessment of the contribution of anthropogenic BC emissions to the observed aerosol concentrations is needed as a first step for assessing potential emission-reduction scenarios. This is the aim of this study, which is done for the entire subcontinent of southern Africa, but with the main focus on the country of South Africa.

This study presents (Sect. 2) and evaluates (Sect. 3) a model setup for southern Africa, using the Weather Research and Forecasting (WRF) model online coupled to air chemistry and aerosol processes (WRF-Chem, Grell et al., 2005; Fast et al., 2006; Skamarock et al., 2008). The evaluation includes a comparison of the model results to different observational and reanalysis data. An important data set is the ground measurements conducted at Welgegund, ca. $100 \mathrm{~km}$ southwest of Johannesburg, detecting both pollution plumes coming from the industrialized and urban areas, as well as air masses representing the regional southern African background. It is one of the only regionally representative and comprehensive long-term inland atmospheric measurement stations (Beukes et al., 2013). In addition, data from observations of particulate matter $\left(\mathrm{PM}_{2.5}\right.$ and $\left.\mathrm{PM}_{10}\right)$ and aerosol optical depth (AOD) are compared with the model results. With two sensitivity studies, the contribution of anthropogenic BC and co-emitted species to aerosol concentrations, AOD, and the impact on atmospheric heating rates is also analyzed (Sect. 4). 
Table 1. General features of the setup, physics and chemistry schemes used in the configuration of the Weather Research and Forecasting model with chemistry (WRF-Chem).

\begin{tabular}{|c|c|c|}
\hline \multicolumn{3}{|l|}{ General features } \\
\hline Domain size & $4-50^{\circ} \mathrm{E}, 5-39^{\circ} \mathrm{S}$ & \\
\hline Modeling time period & 26 Aug-31 Dec 2010 & \\
\hline Resolution & $15 \times 15 \mathrm{~km}, 31$ vertical levels (top at $10 \mathrm{hPa}$ ) & \\
\hline Physics & Scheme & Remarks \\
\hline cloud microphysics & Lin et al. & \\
\hline radiation (shortwave) & Goddard & called every $15 \mathrm{~min}$ \\
\hline radiation (longwave) & Rapid Radiative Transfer Model (RRTMG) & called every $15 \mathrm{~min}$ \\
\hline boundary layer physics & Mellor-Yamada-Janjić (MYJ) & called every time step (90s) \\
\hline land surface processes & Noah LSM & \\
\hline cumulus convection & Grell 3-D & called every time step $(90 \mathrm{~s})$ \\
\hline chemistry & RADM2 with CMAQ aqueous chemistry & chem_opt $=41$ \\
\hline photolysis & Fast-J & called every $15 \mathrm{~min}$ \\
\hline aerosols & MADE/SORGAM & \\
\hline dust & GOCART (online) & dust_opt $=3$ \\
\hline
\end{tabular}

\section{Model and model simulations}

\subsection{Model description and setup}

We apply the Weather Research and Forecasting model (WRF) version 3.5.1 (Skamarock et al., 2008) with chemistry and aerosols (WRF-Chem, Grell et al., 2005; Fast et al., 2006). We use the RADM2 chemistry scheme with the MADE/SORGAM aerosol module and aqueous phase chemistry (CMAQ) (Table 1). RADM2 in combination with the MADE aerosol module has already been widely used in literature (e.g. Grell et al., 2011; Minsenis and Zhang, 2010; Tuccella et al., 2012). Aqueous phase chemistry has been switched on as we expect this to be of relevance particularly when simulating aerosols during the wet season. The model has been set up with one domain covering large parts of southern Africa $\left(4-50^{\circ}\right.$ E, 5-39 $9^{\circ}$ S, Fig. 1) at a horizontal resolution of $15 \mathrm{~km} \times 15 \mathrm{~km}$. WRF-Chem is configured with 31 vertical $\sigma$-levels, of which 14 levels are below $700 \mathrm{hPa}$. The model top is at $10 \mathrm{hPa}$.

We use the Modern-Era Retrospective Analysis for Research and Applications (MERRA) from the National Aeronautics and Space Administration (NASA) as initial and lateral atmospheric boundary conditions (Rienecker et al., 2011). The MERRA data with a horizontal resolution of $0.5^{\circ} \times 0.67^{\circ}$ at 6 -h time intervals and at 32 pressure levels between 1000 and $10 \mathrm{hPa}$ are interpolated to the model grid using the standard WRF Preprocessing System (WPS). European Centre for Medium-Range Weather Forecasts (ECMWF) Interim reanalysis (ERA-Interim) data are used as initial conditions for soil temperature and soil moisture (Dee et al., 2011). The modeled temperature, horizontal wind, humidity, surface pressure, and geopotential height are nudged to the lateral boundary conditions within a buffer zone of 5
Domain overview and elevation $(\mathrm{m})$

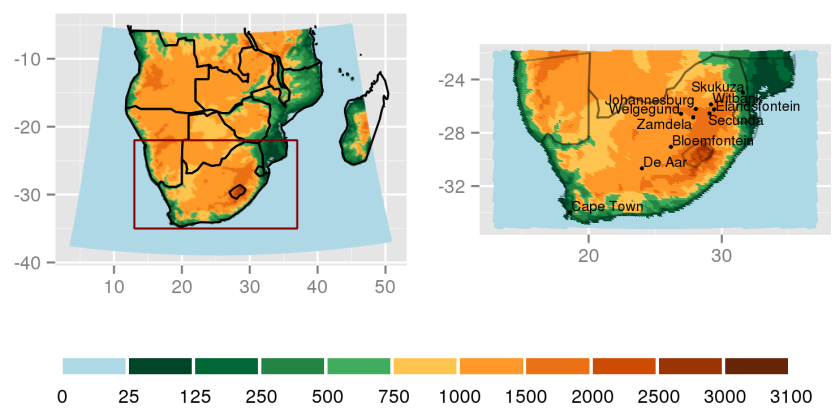

Figure 1. Domain overview and elevation (left), enlarged for South Africa (right), locations of all stations with data used for the model evaluation (see text) and the location of Johannesburg included in the figure.

grid points normal to the lateral boundaries. This buffer zone is excluded in the analyses of the model results shown below. We prescribe sea surface temperatures (SSTs) using the National Oceanic and Atmospheric Administration (NOAA) optimum interpolation (OI) daily analysis (Reynolds et al., 2007). The SST data are based on daily mean satellite observations from the Advanced Very High Resolution Radiometer (AVHRR) and the Advanced Microwave Scanning Radiometer (AMSR) with a horizontal resolution of $0.25^{\circ} \times$ $0.25^{\circ}$. The diurnal SST variation is included in our SST forcing and is calculated following the surface energy budget method of Zeng and Beljaars (2005). Chemical boundary conditions for trace gases and particulate matter are created from simulations with the global chemistry transport Model for Ozone and Related chemical Tracers (MOZART4/GEOS-5, Emmons et al., 2010). 
The physics and chemistry modules used in the WRFChem configuration are summarized in Table 1.

\subsection{Emissions}

Anthropogenic emissions are taken from the EDGAR HTAP v2.2 inventory, released in fall 2013 (EDGAR: Emission Database for Global Atmospheric Research of the Joint Research Centre, JRC, of the European Commission, in cooperation with the Task Force on Hemispheric Transport of Air Pollution, TF HTAP, organized by the United Nations Economic Commission for Europe's Convention on Longrange Transboundary Air Pollution, LRTAP). The data set combines different available national or regional inventories. Gaps are filled by the bottom-up global emission inventory EDGARv4.3, which is calculated based on activity data and corresponding emission factors (see Janssens-Maenhout et al. (2012) for details on v1.0 of the data set; LRTAP-Wiki (2014) for updated information on v2). It should be noted that emission data for southern Africa are entirely based on EDGARv4.3, since currently no comprehensive regional inventories are available. EDGAR HTAP v2.2 reports monthly data for the emissions from the energy, industry, transport and residential sectors and annual data for emissions from shipping and aviation (only takeoff and landing included here). Emission data from small agricultural fires are not available in v2.2 and were therefore taken from v1.0 (annual data for 2005). The authors of the data set recommend using a satellite product for large-scale burning (Janssens-Maenhout et al., 2012), as indicated below.

For biomass burning emissions, the Fire Inventory from the National Center for Atmospheric Research (NCAR) version 1 (FINN, Wiedinmyer et al., 2011) is used. The data are based on daily satellite observations of fires and land cover, which are combined with emission factors and estimated fuel loadings. Fires of approximately $1 \mathrm{~km}^{2}$ size are detected (Wiedinmyer et al., 2011). Biogenic emissions are calculated online by the Model of Emissions of Gases and Aerosols from Nature (MEGAN, Guenther et al., 2006).

\subsection{Simulations}

In this study, we performed a reference run (RR) with the model setup and emissions described above and two sensitivity runs (S1 and S2) with modified emissions but an otherwise identical setup. The model integration covers the time period from 26 August through 31 December 2010. Although September is the first spring month, it is still part of the dry season since rain usually occurs after mid-October. Black carbon concentrations in the interior of South Africa usually peak in September. In contrast, December 2010 is part of the wet season, which has significantly lower ambient $\mathrm{BC}$ levels. The first five days of all experiments were discarded as a spin-up period and excluded from the analysis presented.

\subsubsection{Sensitivity studies}

In the first sensitivity run (S1), all energy-related anthropogenic $\mathrm{BC}$ emissions and emissions from small agricultural fires are set to zero. Following Bond et al. (2013), energyrelated emissions include all emissions from industry, transport (including aviation and shipping), energy production and residential heating. In addition, large scale biomass burning emissions are reduced to $35 \%$ of the initial values. It is assumed that $65 \%$ of the large-scale biomass-burning emissions are caused by humans directly or indirectly. This is based on estimates of the portion of pre-industrial biomass burning emissions of $37 \%$ globally (Bond et al., 2013), as well as $33 \%$ globally and $36 \%$ for southern Africa (Dentener et al., 2006).

When aiming at reducing $\mathrm{BC}$ concentrations it is usually not feasible to only cut the $\mathrm{BC}$ emissions. If emissions from a certain source are reduced, usually also the emissions of co-emitted species such as sulfur dioxide and organic carbon are reduced. Those species can have a cooling impact on the climate. Hence, when assessing the maximum effect of cutting anthropogenic BC emissions on aerosol loadings, or the impact on meteorological variables, it is not sufficient to only consider a case without anthropogenic BC emissions. An integrated assessment of such emission cuts also needs to consider the contribution of the co-emitted components such as organic particles or sulfur dioxide $\left(\mathrm{SO}_{2}\right)$.

The above-mentioned second sensitivity simulation (S2) looks at the impact of both anthropogenic BC and co-emitted (often climate-cooling) aerosols. In addition to the reductions of BC (S1), also the emissions of co-emitted organic carbon $(\mathrm{OC})$, primary sulfate aerosols $\left(\mathrm{SO}_{4}\right)$ and $\mathrm{SO}_{2}$ are reduced in $\mathrm{S} 2$. The emissions are reduced in the same way as $\mathrm{BC}$, i.e. the anthropogenic emissions are set to zero and the biomass burning emissions are reduced to $35 \%$ of the original values. This is a simplifying assumption, as there might be sources among the anthropogenic source categories that do not emit $\mathrm{BC}$ but that do emit $\mathrm{OC}$ or $\mathrm{SO}_{2}$ and vice versa. However, there is not enough information in the anthropogenic emission data used in this study (EDGAR HTAP v2.2) to make additional assumptions on sources emitting $\mathrm{BC}$, but no $\mathrm{OC}$ or $\mathrm{SO}_{2}$, or the other way round. For instance, the ratio of $\mathrm{BC}$ to OC emissions is constant throughout the whole model domain. Ideally, specific reduction factors should be employed. As there is no such information available for southern Africa, the above-described set up is used to estimate the overall effect of anthropogenic BC sources on aerosol loadings and atmospheric heating rates.

The anthropogenic contribution to aerosol concentrations, aerosol optical depth (AOD) and atmospheric heating rates is estimated as the differences between the reference run and the respective sensitivity simulations $(\mathrm{S} 1, \mathrm{~S} 2)$. 


\subsubsection{Model evaluation}

For the model evaluation and a consistency check of the emissions, various observational and reanalysis data have been used (see Sect. 3).

A major data source for evaluating the model results from WRF-Chem is data obtained at the Welgegund measurement station (Fig. 1), the only long-term monitoring station measuring $\mathrm{BC}$ representative of the interior of South Africa (e.g. Venter et al., 2012; Vakkari et al., 2013; Tiitta et al., 2014). The station was set up at Welgegund in 2010 and is jointly operated by the North-West University (South Africa), the University of Helsinki and the Finnish Meteorological Institute. The station consists of an atmospheric monitoring trailer (Petäjä et al., 2013). Measured quantities used in this study include several meteorological parameters (temperature, relative humidity, wind speed and direction, and pressure), trace gases $\left(\mathrm{SO}_{2}, \mathrm{NO} / \mathrm{NO}_{x}, \mathrm{O}_{3}, \mathrm{CO}\right)$ and equivalent $\mathrm{BC}$ determined with a Multi-Angle Absorption Photometer (MAAP) corrected for the filter change artefact (Hyvärinen et al., 2013). There are no major anthropogenic pollution sources close to the station. Beukes et al. (2013) identified five important source regions for air masses analyzed at Welgegund. These include metallurgical industries in the Bushveld Igneous Complex (western and eastern limb) in the north to northeast of Welgegund, the JohannesburgPretoria megacity to the east, the Vaal Triangle (petrochemical, metallurgical and other industries) and the Mpumalanga Highveld (coal mining, coal-fired power plants, petrochemical operations and metallurgical smelters) between the east and south east. Furthermore, large-scale biomass-burning emissions originate mostly from the sector east of the measurement station (from north to south), because the biome in the western sector is drier and there is thus less plant material for combustion available from this sector. Additionally, the sector between north and south to the west of Welgegund is representative of the regional background of southern Africa.

In addition, observations of AOD from two AERONETstations (Holben et al., 1998) and observations of $\mathrm{PM}_{2.5}$ and $\mathrm{PM}_{10}$ provided by the South African Air Quality Information System (SAAQIS) of the South African Weather Service (SAWS) from three stations in the vicinity of the PretoriaJohannesburg megacity are used (Fig. 1). The SAAQIS stations' main purpose is the monitoring of air quality in areas with high air pollution. The stations are classified as urban (Witbank station), residential (Zamdela station) and located in an urban residential area (Secunda station). As these are stations close to anthropogenic, non-biomass burning emission sources, aerosol concentrations are expected to be mainly dominated by local anthropogenic emissions. Hence, these comparisons are used as a consistency check for the emission data used here.

\section{Comparison with observations and reanalysis data}

\subsection{Meteorology}

\subsubsection{WRF-Chem model results for southern Africa}

The comparison of the sea-level pressure modeled with WRF-Chem to ERA-Interim reanalysis data (Dee et al., 2011) shows that WRF-Chem represents the common features of the southern African pressure distribution well (Fig. 2a). In September, over the south Atlantic and the south Indian Ocean, the edges of two subtropical highs can be identified. Another high is over the east coast of the continent, which is part of the high pressure belt around $30^{\circ} \mathrm{S}$ that influences the daily weather patterns of southern Africa (Tyson and Preston-Whyte, 2000). The spatial correlation between the WRF-Chem monthly mean and the ERA-Interim reanalysis monthly mean in September is high $(r=0.95)$ and the domain-averaged mean bias with respect to the ERA-Interim reanalysis is small $(-0.6 \mathrm{hPa})$. In December, both WRFChem results and ERA-Interim reanalysis show that the low pressure area over the northern part of the model domain associated with the Intertropical Convergence Zone (ITCZ) is moving southwards compared to September, resembling the easterly low situation, which is usually the dominant synoptic situation in December (Tyson and Preston-Whyte, 2000). This constellation, associated with the ITCZ moving southwards at the beginning of the wet season, is responsible for strong precipitation over the subcontinent. The spatial correlation between the two data sets is slightly lower in December $(r=0.79)$ than in September. The domain-averaged monthly mean pressure of the WRF-Chem results is biased with respect to the ERA-Interim reanalysis by $-2.6 \mathrm{hPa}$ in December.

In September 2010, WRF-Chem simulated over the area within the northern low pressure region some precipitation, possibly indicating too early of an onset of the rainy season (Fig. 2b). Compared with the Global Precipitation Climatology Project (GPCP) precipitation data (Huffman et al., 2001), WRF-Chem overestimated the precipitation amounts in September 2010 as most parts of the subcontinent do not receive any significant amount of precipitation. The mean bias for the whole model domain is $1.11 \mathrm{mmday}^{-1}$. In December, the WRF-Chem results show large amounts of precipitation over the whole eastern part of the subcontinent, including Madagascar and the Mozambique Channel. WRFChem strongly overestimated the amounts of precipitation during all months of the modeled period, with a maximum monthly mean bias of $+6.47 \mathrm{~mm} \mathrm{day}^{-1}$ (domain average) in December $2010(+200 \%)$. In addition to the northeastern part of the model domain and the Mozambique Channel, precipitation in the model was also strongly overestimated near the Drakensberg Mountains and over/on the edges of the South African Highveld. The spatial correlation is rather low in both September $(r=0.38)$ and December $(r=0.36)$. 

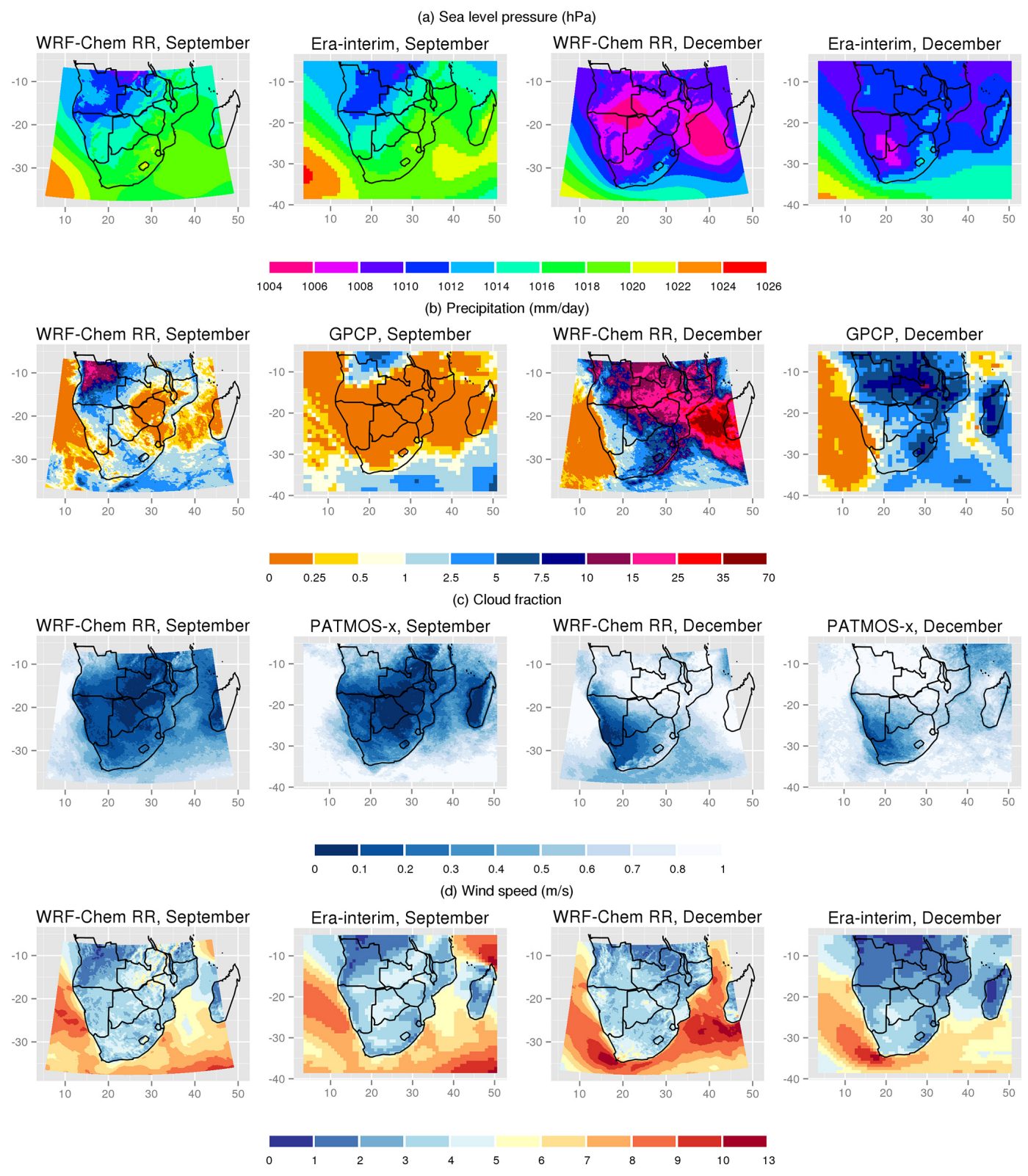

Figure 2. Selected meteorological variables, monthly means for September and December 2010, comparison of WRF-Chem model results with different data sets (a - sea level pressure, comparison with ERA-Interim reanalysis data, b - precipitation amount, comparison with GPCP data, $\mathbf{c}$ - cloud fraction, comparison with PATMOS-x satellite data, $\mathbf{d}$ - wind speed, comparison with ERA-Interim reanalysis data).

It should, however, be noted that satellite-based precipitation data sets such as the GPCP data over southern Africa also include uncertainties. It is known, for instance, that satellitebased precipitation estimates tend to underestimate rainfall amounts during the dry seasons (Huffman et al., 2001, 2007). Furthermore, underestimation of precipitation is documented for the GPCP data in areas of complex terrain (Huffman et al., 2001), which applies to the region around the Drakensberg Mountains and the edge of the Highveld, i.e. the escarpment.
Previous studies have shown that the extent and location of the model domain of a regional model is important when running simulations over South Africa (Crétat et al., 2011, and references therein). However, in a pre-study different configurations of WRF have been tested and the precipitation bias found in all simulations did not show any significant improvement when adjusting the extent of the model domain to, for instance, include Madagascar. Precipitation biases have been reported in the literature when studying South African meteorology with different models. Results suggest that this phenomenon might be related to too strong of an atmospheric 
water cycle and too strong of an advection of moisture in the models. Another reason for the precipitation bias over the continent might be the complex topography (Crétat et al., 2011), as for example suggested by the overestimation near the Drakensberg mountains and the edge of the Highveld. Crétat et al. (2011) have shown that the precipitation bias in WRF depends partly on the choice of the cumulus scheme in combination with the PBL and microphysics schemes. However, their setup providing best results could not be used in combination with WRF-Chem as certain chemistry options such as aqueous phase chemistry are not available for all convection schemes.

In September 2010, most parts of the subcontinent including the northern parts of South Africa, Botswana and Zimbabwe were almost entirely cloud free (Fig. 2c). The modeled monthly mean cloud-free area is somewhat larger than the one obtained from the PATMOS-x satellite data (Heidinger et al., 2014). The cloud fraction in the model is particularly larger than observed in regions where precipitation is simulated, but the overall bias is negative with $-13 \%(-27 \%)$ in September and $-5 \%(-7 \%)$ in December. The spatial correlation between the two data sets is high $(r=0.85)$ in September. As already seen for sea level pressure and precipitation, the spatial correlation is smaller for December 2010 ( $r=0.57)$, which might be related to more frequent and stronger convection in December, which is difficult to capture with a model.

The monthly mean $2 \mathrm{~m}$ temperature is modeled well in September 2010 (not shown), showing only a small domain averaged bias of $0.4^{\circ} \mathrm{C}$ compared with the ERA-Interim reanalysis data and a high spatial correlation $(r=0.93)$. In December, the modeled $2 \mathrm{~m}$ temperature is lower than the ERAInterim reanalysis particularly in the areas above the continent where a positive precipitation bias is found. The overall mean bias of the model results compared to the ERA-Interim reanalysis in December is small with $-0.03{ }^{\circ} \mathrm{C}$, and the spatial correlation is still high with $(r=0.91)$.

The outgoing longwave radiation (OLR, not shown) over some parts of the continent is up to 25 to $50 \mathrm{~W} \mathrm{~m}^{-2}$ lower than the PATMOS-x satellite data for September 2010. Again, the bias is particularly high in areas with a strong bias in precipitation, with a domain-averaged monthly mean bias of $-21.4 \mathrm{~W} \mathrm{~m}^{-2}(-7 \%)$. The spatial correlation with the PATMOS-x data is $r=0.85$. Likewise, in December, the modeled OLR over the Mozambique Channel is up to $100 \mathrm{~W} \mathrm{~m}^{-2}$ smaller than in the satellite data, with a domainaverage bias of the monthly mean of $-17.3 \mathrm{~W} \mathrm{~m}^{-2}(-7 \%)$ in December. The spatial correlation of the OLR is $r=0.72$ in December 2010. The underestimation by the model in areas with large amounts of precipitation suggests that the cloud top heights are overestimated in WRF-Chem, even though the cloud fraction is underestimated. This in turn suggests that the cloud thickness is overestimated by the model, which could explain the stronger than observed precipitation. The cloud and precipitation biases can also explain the negative bias in the surface temperature in regions with significant precipitation. The model biases of the different variables are consistent and might be the result of the difficulty in reproducing the observed convection, clouds and precipitation with WRF.

Compared with the ERA-Interim reanalysis, WRF-Chem captures the monthly mean $10 \mathrm{~m}$ wind speed (Fig. 2d) fairly well in the dry season (September), with some local positive, as well as negative deviations. The mean bias averaged over the whole model domain is $-0.4 \mathrm{~m} \mathrm{~s}^{-1}(-8 \%)$ in September and $1.3 \mathrm{~m} \mathrm{~s}^{-1}(30 \%)$ in December. The spatial correlation is fairly high with $r=0.87$ in September and $r=0.85$ in December.

\subsubsection{Comparison to measurements at Welgegund}

For comparing the model results to measurements done at the Welgegund station, the modeled daily means of all variables considered except precipitation are averaged over the $3 \times 3$ nearest grid points surrounding the measurement station. The WRF-Chem precipitation data are compared to TRMM satellite data (Huffman et al., 2007) and averaged over the 25 $(5 \times 5)$ nearest grid points to be comparable to the TRMM nine grid point average. All the comparative data are presented in Fig. 3 and Table 2.

The TRMM data show that precipitation events become more frequent from mid-October 2010 on, with almost no precipitation observed beforehand. From this, we qualitatively derive the beginning of the rainy season around midOctober 2010. In contrast, the beginning of the rainy season in the model is about 1 month too early. In addition, the amplitudes of the precipitation events are much higher, at times up to three times as high as the TRMM values (e.g. in midDecember with ca. $20 \mathrm{~mm} \mathrm{day}^{-1}$ as indicated by the TRMM data and more than $60 \mathrm{~mm} \mathrm{day}^{-1}$ in WRF-Chem). The modeled time series of the precipitation in September is not correlated with the TRMM data $(r=-0.09)$. In December, there is a rather low correlation $(r=0.20)$, and a mean bias of $2.17 \mathrm{~mm} \mathrm{day}^{-1}(44 \%)$.

The monthly mean specific humidity measured at Welgegund increases from $5.39 \mathrm{~g} \mathrm{~kg}^{-1}$ in September to $11.86 \mathrm{~g} \mathrm{~kg}^{-1}$ in December 2010. This increase is captured qualitatively by the model, but the WRF-Chem results are positively biased in September $\left(+0.96 \mathrm{~g} \mathrm{~kg}^{-1},+18 \%\right)$, October and November, with the bias decreasing over time. In December 2010, the modeled monthly mean specific humidity is in good agreement with the observations with a mean bias of $-1.5 \%\left(-0.18 \mathrm{~g} \mathrm{~kg}^{-1}\right)$. The temporal correlation between modeled and measured daily mean values is high in September $(r=0.76)$. While the monthly mean is modeled well in December 2010, the time series of the daily values are uncorrelated $(r=0.06)$, meaning that the model does not capture the day-to-day pattern.

The monthly mean $2 \mathrm{~m}$ temperature at Welgegund does not vary much over the whole modeling period, with $19.4{ }^{\circ} \mathrm{C}$ 
Table 2. Monthly mean of modeled and observed meteorology, BC and selected trace gases, mean bias of the WRF-Chem daily means with respect to observations and temporal correlation coefficient (Pearson) of daily means over 1 month or the whole period September to December 2010 (all). Observational data are station measurements at Welgegund for all variables except for precipitation, which is obtained from the TRMM satellite data.

\begin{tabular}{|c|c|c|c|c|c|}
\hline Variable & Month & $\begin{array}{l}\text { WRF-Chem mean and } \\
\text { standard deviation }\end{array}$ & $\begin{array}{l}\text { Measurements mean } \\
\text { and standard deviation }\end{array}$ & Mean bias & $\begin{array}{r}\text { Correlation } \\
\text { coefficient }\end{array}$ \\
\hline \multicolumn{6}{|l|}{ Welgegund } \\
\hline \multirow{3}{*}{$\begin{array}{l}\text { Specific humidity } \\
\left(\mathrm{g} \mathrm{kg}^{-1}\right)\end{array}$} & September & $6.35 \pm 2.09$ & $5.39 \pm 2.00$ & 0.96 & 0.76 \\
\hline & December & $11.76 \pm 1.67$ & $11.86 \pm 1.78$ & -0.18 & 0.06 \\
\hline & All & $9.67 \pm 2.98$ & $8.80 \pm 3.29$ & 0.87 & 0.78 \\
\hline \multirow{3}{*}{$\begin{array}{l}\text { Precipitation } \\
\left(\mathrm{mmday}^{-1}\right)\end{array}$} & September & $1.0 \pm 2.4$ & $0.001 \pm 0.002$ & 1.0 & 0.09 \\
\hline & December & $7.1 \pm 12.9$ & $4.9 \pm 5.2$ & 2.2 & 0.20 \\
\hline & All & $5.6 \pm 10.7$ & $2.1 \pm 4.3$ & 3.5 & 0.26 \\
\hline \multirow{3}{*}{$\begin{array}{l}2 \mathrm{~m} \text { temperature } \\
\left({ }^{\circ} \mathrm{C}\right)\end{array}$} & September & $19.6 \pm 2.4$ & $19.4 \pm 2.4$ & 0.2 & 0.84 \\
\hline & December & $20.0 \pm 1.6$ & $21.0 \pm 2.0$ & -1.0 & 0.44 \\
\hline & All & $19.8 \pm 2.1$ & $20.6 \pm 2.6$ & -0.9 & 0.69 \\
\hline \multirow{3}{*}{$\begin{array}{l}10 \mathrm{~m} \text { wind speed } \\
\left(\mathrm{m} \mathrm{s}^{-1}\right)\end{array}$} & September & $4.8 \pm 1.7$ & $5.0 \pm 1.6$ & -0.2 & 0.77 \\
\hline & December & $3.9 \pm 1.4$ & $6.1 \pm 1.2$ & -2.2 & -0.07 \\
\hline & All & $4.3 \pm 1.6$ & $5.6 \pm 1.6$ & -1.3 & 0.29 \\
\hline \multirow{5}{*}{$\begin{array}{l}\text { BC concentration } \\
\left(\mu \mathrm{g} \mathrm{m}^{-3}\right)\end{array}$} & September & $0.73 \pm 0.35$ & $1.47 \pm 0.70$ & -0.74 & 0.62 \\
\hline & October & $0.43 \pm 0.29$ & $0.88 \pm 0.50$ & -0.45 & 0.67 \\
\hline & November & $0.32 \pm 0.20$ & $0.31 \pm 0.13$ & 0.01 & 0.11 \\
\hline & December & $0.25 \pm 0.15$ & $0.19 \pm 0.11$ & 0.06 & 0.37 \\
\hline & All & $0.43 \pm 0.31$ & $0.71 \pm 0.67$ & -0.28 & 0.66 \\
\hline \multirow{3}{*}{$\begin{array}{l}\mathrm{CO} \\
(\mathrm{ppb})\end{array}$} & September & $170 \pm 41$ & $201 \pm 60$ & -31 & 0.78 \\
\hline & December & $100 \pm 15$ & $115 \pm 17$ & -14 & 0.40 \\
\hline & All & $131 \pm 38$ & $161 \pm 60$ & -29 & 0.78 \\
\hline \multirow{3}{*}{$\begin{array}{l}\mathrm{O}_{3} \\
(\mathrm{ppb})\end{array}$} & September & $42 \pm 7$ & $50 \pm 10$ & -8 & 0.82 \\
\hline & December & $29 \pm 6$ & $34 \pm 4$ & -5 & 0.14 \\
\hline & All & $34 \pm 8$ & $42 \pm 10$ & -8 & 0.73 \\
\hline \multirow{3}{*}{$\begin{array}{l}\mathrm{SO}_{2} \\
(\mathrm{ppb})\end{array}$} & September & $1.8 \pm 2.1$ & $1.8 \pm 1.2$ & -0.04 & 0.31 \\
\hline & December & $2.6 \pm 2.3$ & $1.0 \pm 0.9$ & 1.6 & 0.44 \\
\hline & All & $2.2 \pm 2.4$ & $1.3 \pm 1.1$ & 0.9 & 0.21 \\
\hline \multirow{3}{*}{$\begin{array}{l}\mathrm{NO}_{x} \\
(\mathrm{ppb})\end{array}$} & September & $4.6 \pm 5.4$ & $3.0 \pm 1.8$ & 1.7 & 0.75 \\
\hline & December & $9.2 \pm 8.4$ & $2.5 \pm 1.2$ & 6.7 & 0.36 \\
\hline & All & $6.8 \pm 7.4$ & $3.4 \pm 1.6$ & 3.4 & 0.19 \\
\hline
\end{tabular}

measured in September and $21.0^{\circ} \mathrm{C}$ in December. It is simulated quite well in September, with only a slight mean warm bias of $+0.2^{\circ} \mathrm{C}$. From October on, the modeled monthly means are biased slightly negative. In December, the mean bias is $-1.0^{\circ} \mathrm{C}$. As is evident from Fig. 3, as well as a comparison of the standard deviations (SDs, not shown), the model captures the day-to-day variability well. From October on, the timing of the modeled minima and maxima, as well as the minimum and maximum values agree less well with the observations. This is also seen in the temporal correlation coefficient of the daily means, which decreases from September $(r=0.84)$ to December $(r=0.44)$. The temporal correlation over the whole period is $r=0.69$.
The monthly mean $10 \mathrm{~m}$ wind speed measured at Welgegund varies between $5.0 \mathrm{~m} \mathrm{~s}^{-1}$ (September) and $6.1 \mathrm{~m} \mathrm{~s}^{-1}$ (December). The model results are biased negatively in all 4 months, with the smallest bias in September $\left(-0.2 \mathrm{~m} \mathrm{~s}^{-1}\right.$, $-4 \%)$ and the largest bias in December $\left(-2.2 \mathrm{~ms}^{-1}\right.$, $-36 \%)$. From the beginning of October, the model has some difficulty in capturing the maximum daily mean wind speeds well, and underestimates the minimum daily mean wind speeds. The temporal correlation coefficient indicates that the daily mean wind speed is captured better in September $(r=0.77)$, while the model results and the measurements are uncorrelated in December $(r=-0.07)$. 


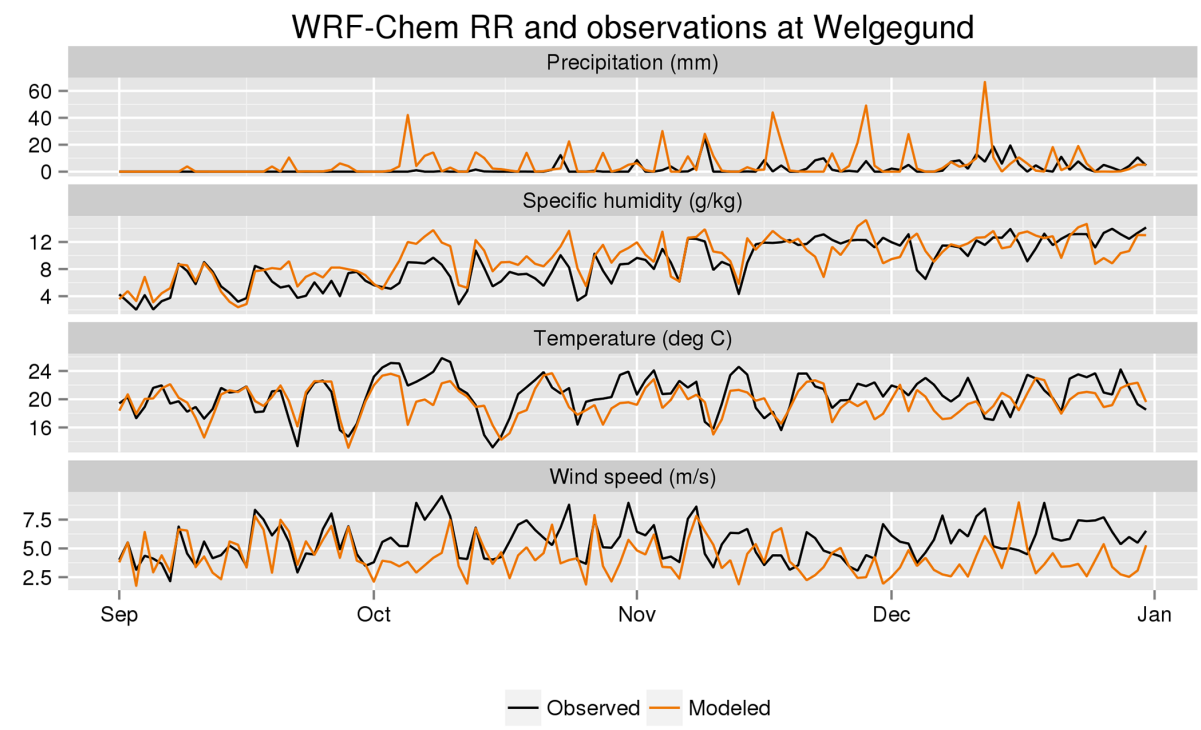

Figure 3. WRF-Chem model results of meteorological variables at Welgegund in comparison with Welgegund station measurements and precipitation satellite data (TRMM). Shown are daily means (daily sums in the case of precipitation).

Averaged over the whole modeling period, the modeled $10 \mathrm{~m}$ wind direction deviates slightly from the measured wind direction at Welgegund (not shown). While the frequency of northerly winds - the dominant wind direction - is modeled quite well (around $27 \%$ ), the portion of wind coming from the northeast is clearly underestimated (less than $10 \%$ in the model compared with around $20 \%$ in the measurements). In contrast, the northwesterly wind direction is slightly overestimated. Wind coming from the southwest to the southeast does not play a major role at Welgegund, which is correctly reproduced by the model. The overestimation of wind coming from the northeast by the model is particularly prevalent in September (not shown). In November the modeled main wind direction is shifted only slightly to the east compared with the observations. The wind direction bias in October and December is small.

\subsubsection{Atmospheric profiles and inversion layer height}

For an analysis of the simulation of the atmospheric vertical structure, WRF-Chem temperature and humidity profiles were compared with available radiosonde measurements at Pretoria, Bloemfontein, de Aar and Cape Town (MetOffice, 2006, see Fig. 1 for the location of the stations). As data availability for 2010 is sparse, average profiles of measurements obtained between the years 1997 and 2012 are used for comparison. This is done as a consistency check to see whether the model is able to reproduce the main climatological features of the vertical profiles. The radiosonde measurements are not directly comparable to the WRF-Chem model results. The comparison shows that WRF-Chem is able to capture the basic (climatological) features of the vertical profiles of temperature and humidity with the modeled vertical profiles being within the variability given by two times the standard deviation ( $2 \sigma$-range, not shown).

In addition to the average temperature and humidity profiles, the inversion layer height has been calculated from each measured vertical profile and from WRF-Chem at the times corresponding to the radiosonde ascents. The inversion height is determined according to the following criteria, following Cao et al. (2007):

- An inversion is characterized by increasing temperature with height and decreasing relative humidity.

- If present, the inversion is located between 825 and $350 \mathrm{hPa}$ (inland stations) and between 950 and $600 \mathrm{hPa}$ in Cape Town (elevation $42 \mathrm{~m}$ ). The lowest couple of hundred meters are excluded to exclude radiative inversions at the surface.

- Only inversions with temperatures above $0{ }^{\circ} \mathrm{C}$ are searched for in order to avoid artifacts caused by falling ice particles.

- If there are several inversions within one profile, the inversion with the largest decrease in relative humidity is chosen.

In Pretoria the monthly mean inversion height varies between 740 and $710 \mathrm{hPa}$ between September and December (Fig. 4). The inter-annual variability given by the 25 th and the 75 th percentiles lies between 800 and $650 \mathrm{hPa}$. The mean inversion height is slightly lower in September and October than in November and December. Similar behavior is also found at the other three radiosonde stations. The mean inversion height modeled with WRF-Chem at the four stations is generally slightly lower by about $50 \mathrm{hPa}$ than the mean inversion 


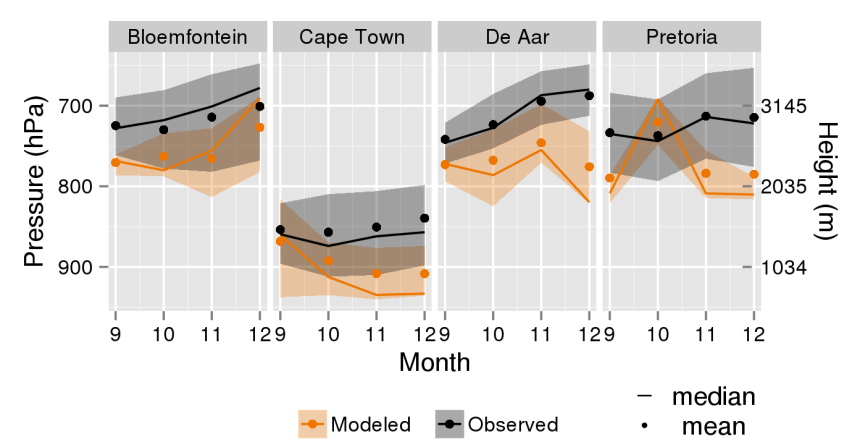

Figure 4. Inversion heights for each month (September-December) and four different radiosonde stations, lines represent the median, shaded areas the 25 th and 75 th percentiles, dots the mean values.

height obtained from the radiosonde measurements (mostly between ca. 800 and $750 \mathrm{hPa}$ for the inland stations, with few exceptions). A comparison of the frequencies of measured and modeled inversions suggests that WRF-Chem might underestimate the number of days with an inversion present. We discuss the role of the inversion layer height for near-surface concentrations of BC in Sect. 3.2.3.

\subsection{Black Carbon}

\subsubsection{Modeled monthly mean concentrations}

Figure 5 shows the modeled monthly mean near-surface BC concentrations for September, October, November and December 2010, with "near-surface" meaning the lowest model layer, centered around about $30 \mathrm{~m}$ above the ground. The highest monthly mean $\mathrm{BC}$ concentrations in September are modeled in the Johannesburg-Pretoria area with values up to $15 \mu \mathrm{g} \mathrm{m}^{-3}$. In Zimbabwe, where the emission inventory also shows relatively high anthropogenic emissions, the BC concentrations are comparable to the Johannesburg-Pretoria levels (up to $2.5 \mu \mathrm{g} \mathrm{m}^{-3}$ ). In the north of the model domain at the border between Zambia and Angola mean BC concentrations are as high as $5 \mu \mathrm{g} \mathrm{m}^{-3}$ with biomass burning being the main $\mathrm{BC}$ source in that area. Over land, the lowest modeled monthly mean $\mathrm{BC}$ concentrations are found in the southeast of South Africa in the dryer Karoo regions, with values of less than $0.1 \mu \mathrm{g} \mathrm{m}^{-3}$. This region is relatively far from both anthropogenic sources and from large-scale biomass burning areas.

It can also be seen from Fig. 5 that the mean modeled concentrations are generally much higher in September 2010, which corresponds to the end of the dry season in the model, than in the following months. Especially in November and December, concentrations are lower, possibly due to a combination of higher removal of $\mathrm{BC}$ from the atmosphere (wet scavenging), the lack of large scale biomass burning as a major source and a less stable atmosphere (i.e. a smaller number of days with an inversion).
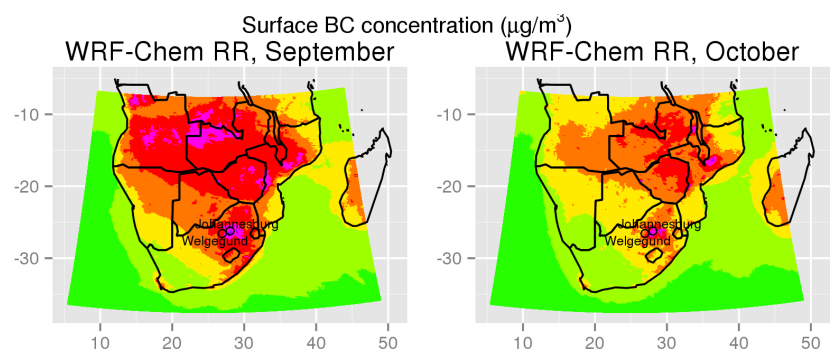

WRF-Chem RR, November

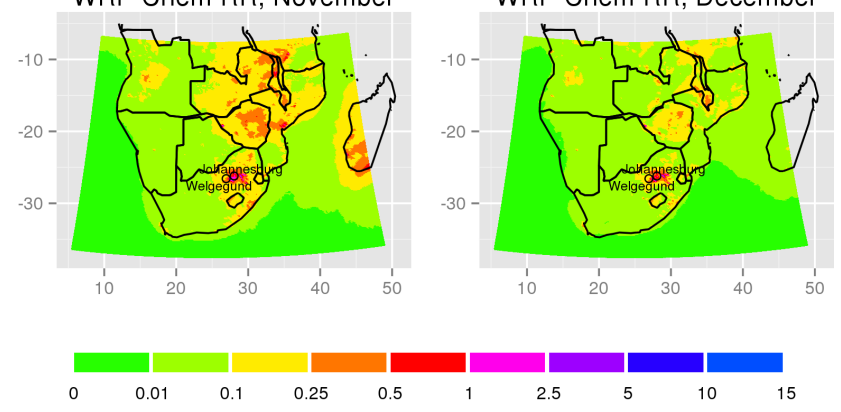

Figure 5. Monthly mean near-surface BC concentrations (lowest model layer) modeled with WRF-Chem, SeptemberDecember 2010.

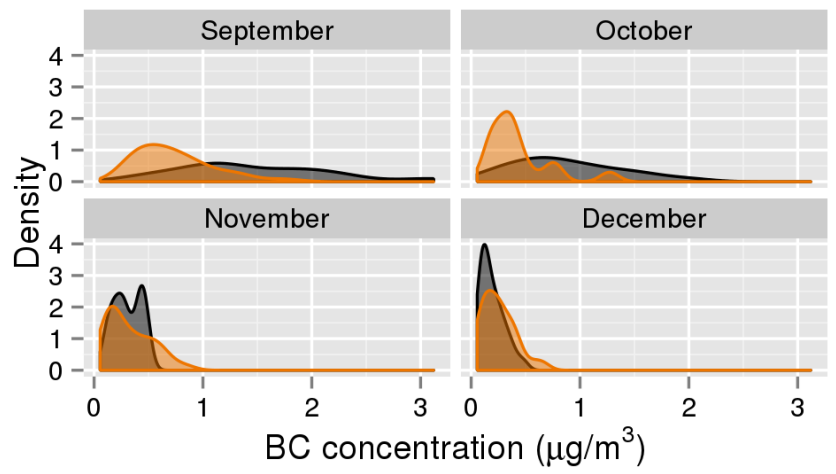

Observed Modeled

Figure 6. BC concentrations at Welgegund, measured and modeled with WRF-Chem: probability density functions (PDFs) for September-December 2010. The PDFs are calculated from the observed 15 -min values and the 3-hourly values (instantaneous values) from the model results.

For comparison, the measured annual mean in Berlin, Germany ranges between around $2 \mu \mathrm{g} \mathrm{m}^{-3}$ at urban background stations and around $3.5 \mu \mathrm{g} \mathrm{m}^{-3}$ at measurement sites close to busy roads (2012 values, Senatsverwaltung für Stadtentwicklung und Umwelt, 2013). BC concentrations are especially high in some regions in Asia, e.g. in Kathmandu, Nepal, with an annual mean measured as $8.4 \mu \mathrm{g} \mathrm{m}^{-3}$ (Sharma et al., 2012). 


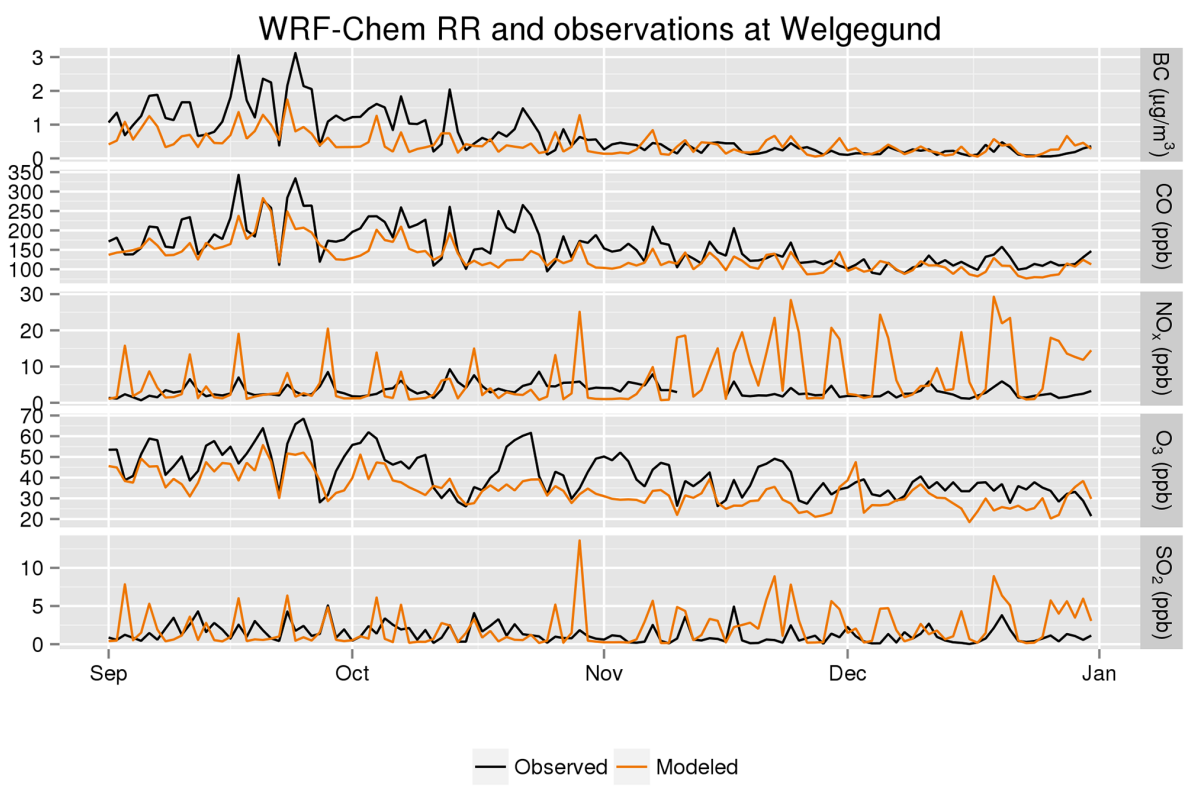

Figure 7. Comparison of modeled daily means of BC and gaseous species with station measurements at Welgegund.

\subsubsection{Comparison with Welgegund data}

At Welgegund the measured monthly mean BC concentrations decrease steadily from September (dry season) to December (wet season), with $1.47 \mu \mathrm{g} \mathrm{m}^{-3}$ in September, $0.88 \mu \mathrm{g} \mathrm{m}^{-3}$ in October, $0.31 \mu \mathrm{g} \mathrm{m}^{-3}$ in November and $0.19 \mu \mathrm{g} \mathrm{m}^{-3}$ in December (Table 2). The maximum daily mean concentrations in September are about $3 \mu \mathrm{g} \mathrm{m}^{-3}$ and in October about $2 \mu \mathrm{g} \mathrm{m}^{-3}$. As is evident from Fig. 6 the observed probability density function (PDF) for the mostly dry month of October is similar to the one for September, while the PDFs for the wetter months of November and December are much narrower and have distinct peaks at BC concentrations below $0.5 \mu \mathrm{g} \mathrm{m}^{-3}$.

The monthly BC means modeled with WRF-Chem are generally smaller than those shown by the measurements in September and October $\left(0.73 \mu \mathrm{g} \mathrm{m}^{-3}\right.$ and $0.43 \mu \mathrm{g} \mathrm{m}^{-3}$, corresponding to a bias of -50 and $-51 \%$ ) and slightly higher than observed in November $\left(0.32 \mu \mathrm{g} \mathrm{m}^{-3}\right.$, biased by $\left.3 \%\right)$ and in December (just above $0.25 \mu \mathrm{g} \mathrm{m}^{-3}$, biased by $32 \%$ ). Over the whole period, the mean bias is negative $\left(-0.28 \mu \mathrm{g} \mathrm{m}^{-3}\right.$, $-39 \%)$. The modeled PDFs in September and October are too narrow and the peaks around ca. $0.5 \mu \mathrm{g} \mathrm{m}^{-3}$ are at concentrations too low compared with the measurements. The modeled PDF for October resembles rather a wet season PDF than a dry season PDF, which is in line with the results we described for the simulated precipitation, showing that the beginning of the wet season is modeled ca. 1 month too early.

Even though the magnitude of the peak values and the average of the daily mean time series are underestimated in September and October, the time series of modeled and measured daily means are reasonably well correlated (tempo- rally) with correlation coefficients of $r=0.62$ (September) and $r=0.67$ (October) (Fig. 7 and Table 2).

As the Welgegund station is not directly surrounded by sources of BC, apart from smaller local grass fires, most of the $\mathrm{BC}$ measured at Welgegund is transported to the station (Tiitta et al., 2014). Thus, the BC concentrations at Welgegund are strongly impacted by how effectively pollutants are transported from the industrialized areas, as well as from the biomass-burning areas mainly located in the sector east of the station. $96 \mathrm{~h}$ back-trajectories of air masses at Welgegund (Beukes et al., 2013) show that anthropogenic BC can be transported to Welgegund in different ways: either directly, with wind at Welgegund coming from the northeast to east, or by air masses re-circulated over the continent with wind at Welgegund from the north.

The pollution roses shown in Fig. 8 give a first estimate for the direction from which $\mathrm{BC}$ is transported to the station. The measurements show that very high concentrations are most frequently observed during periods with wind from the north or northeast corresponding to the above-mentioned transportation pathways. These pathways are reproduced by the model, which simulates the highest $\mathrm{BC}$ concentrations with wind coming from the northern to eastern sectors. However, as previously mentioned and visible from Fig. 8, the main wind directions in the model are shifted from the northeast to the northwest.

\subsubsection{Discussion}

Several factors are likely to influence the modeled BC concentration, including the bias in modeled meteorology (e.g. precipitation, wind direction), a low quality of the emis- 


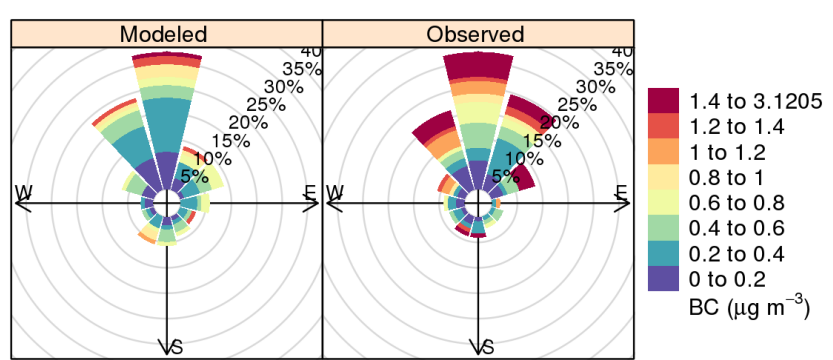

Frequency of counts by wind direction (\%)

Figure 8. Pollution rose at Welgegund, comparison of WRF-Chem model results and station measurements. The plot shows the $\mathrm{BC}$ concentration modeled/measured for wind coming from the indicated directions and is created from the non-averaged data, e.g. 15min values for the observations and 3-h values for the model results.

sion inventories, the choice of chemical boundary conditions or uncertainties and limitations in the representations of important processes in the model (e.g. the particle size distribution, the parametrization of convection or the boundary layer).

A too-early beginning of the rainy season and an overestimation of the precipitation amounts are likely to result in a too-strong wet deposition of aerosols including $\mathrm{BC}$ in the model and are likely two reasons contributing to the underestimation of the modeled mean BC concentrations particularly during the dry season at Welgegund. This is especially the case in October 2010, being mostly dry in the observations, but showing significant precipitation in the model. As $\mathrm{BC}$ has a typical atmospheric residence time of a few days, a full quantitative analysis on the impact of the overestimation in precipitation on modeled $\mathrm{BC}$ concentrations would require back-trajectories for several days, which is beyond the scope of this study. We argue qualitatively that the modeled overestimation of precipitation might contribute to the modeled underestimation of $\mathrm{BC}$, as we know that $\mathrm{BC}$ has to be transported to the measurement site, because there are no significant sources close by.

Highest $\mathrm{BC}$ concentrations are modeled with wind from the northern to eastern wind sectors, which is consistent with the measurements at Welgegund. However, the shift in the modeled main wind direction to the northwest compared with the measurements likely also contributes to the abovediscussed model bias in the BC concentrations. This is especially the case in September when the northeastern component of the wind is underestimated in the model, which is the second most frequently observed wind direction at Welgegund in this month. BC peak concentrations are measured particularly during these wind episodes.

Furthermore, the negative bias in modeled wind speed at Welgegund might also contribute to an underestimation of $\mathrm{BC}$ transported to Welgegund. However, this bias is fairly small and is likely not a main reason for the underestimation of modeled BC during the dry season.
The lack of BC transported from the industrialized and urban areas to Welgegund in September being a reason for the underestimation of modeled $\mathrm{BC}$ at the measurement station is further supported by the plots in Fig. 5 showing the geographical distribution of the modeled BC: higher BC concentrations resulting from urban emissions are found downwind of Pretoria and Johannesburg, while the Welgegund station is located just outside the area of the urban pollution plume with typical concentrations between 1 and $2.5 \mu \mathrm{g} \mathrm{m}^{-3}$ inside the plume. When comparing the $\mathrm{BC}$ concentrations measured at Welgegund to the model results at an equivalent location of Welgegund situated downwind of the modeled main wind direction at the same distance from the urban areas around Johannesburg and Pretoria as the Welgegund site (not shown), model and measurements are in much better agreement during the entire simulation period: in September, the modeled mean $\mathrm{BC}$ concentration at the equivalent location is above $1 \mu \mathrm{g} \mathrm{m}^{-3}$, and around $0.5 \mu \mathrm{g} \mathrm{m}^{-3}$ in October, reducing the model bias to values between -30 and $-40 \%$. This further supports that the modeled meteorology plays an important role in explaining the model bias of the BC concentration at Welgegund.

In principle, the height and strength of inversion layers can also influence the BC concentrations. A too-low number of inversion days in the model, i.e. an underestimation of days with stable atmospheric conditions, could result in pollutants being too-well mixed and in concentrations being too small. A too low inversion height in the model would increase the concentrations in the boundary layer during the inversion events and might counteract some of this. While the inversion height is captured quite well in the model, the number of inversion days is probably underestimated. The scarcity of radiosonde data in the fall of 2010 does not allow for a more detailed analysis of the inversion height statistics and a comparison of the modeled BC concentrations on days with and without inversion layers during the dry season. However, inversion layers are not thought to play a dominant role for the $\mathrm{BC}$ concentrations measured at Welgegund as the concentrations are dominated by transport processes over at least $100 \mathrm{~km}$ to the station allowing for ample mixing. This is supported by the finding that BC concentrations at Welgegund do not show a distinct diurnal cycle in September 2010 (not shown), which would be expected if the inversion played a significant role.

In general, the modeled meteorology and the modeled BC time series agree reasonably well with the observations at Welgegund during the dry season. A major contribution to the lower correlation of modeled meteorology, as well as the $\mathrm{BC}$ daily means with the Welgegund measurements during the wet season is likely caused by the difficulty of the model in reproducing the observed convection activity, which plays a major role particularly during the wet season.

Emission inventories of energy-related emissions of BC for Africa have rather large uncertainties (Bond et al., 2013). This certainly plays an important role for the modeled BC 
concentrations, as the modeled concentrations can only be as good as the emission data used as model input. For example, day-to-day variations in $\mathrm{BC}$ concentrations due to the variability of energy-related anthropogenic $\mathrm{BC}$ emissions cannot be represented by the model as the emission inventory used (EDGAR HTAP) has a time resolution of one month or less. However, the analysis in this study suggests that the energy-related anthropogenic emissions are at least within the correct order of magnitude, as further elaborated in Sect. 3.3. Furthermore, the FINN biomass burning emission inventory with a time resolution of one day seems to capture the biomass burning events relatively well. This is suggested by the fairly good temporal correlation of the modeled daily means of BC with the measurements during the dry season, as biomass burning episodes play an important role for high levels of BC at Welgegund during the dry season (Tiitta et al., 2014).

Black carbon at Welgegund is measured as equivalent BC. It is therefore possible that $\mathrm{BC}$ is overestimated as additional non-BC absorbing material is also classified as BC. Studies disagree on the exact amplitude of the measurement uncertainty of the MAAP ranging from very little increase in absorption due to non-absorbing coatings of $\mathrm{BC}$ particles (e.g. Lack et al., 2012; Cappa et al., 2012, 2013) to a factor of two (e.g. Shiraiwa et al., 2010; Wang et al., 2014). However, we do not believe that the measurement uncertainty alone could explain a bias of $50 \%$ in the dry season, but rather a combination of the model deficiencies and uncertainties discussed above.

\subsection{Aerosol optical depth and particulate matter concentrations}

\subsubsection{Aerosol optical depth}

Compared to the MOderate Resolution Imaging Spectroradiometer (MODIS) (Remer et al., 2005) satellite observations (MODIS Terra and Aqua monthly level-3 data, collection 5.1) of the aerosol optical depth (AOD), WRF-Chem captures the main geographical pattern over southern Africa qualitatively correctly, as exemplarily shown for September (Fig. 9), with high AOD values (larger than 0.3) in the northwest of the model domain, where biomass burning is strong, and a lower AOD in South Africa (mostly between 0.1 and $0.3)$.

Especially in the northwest of the model domain over the ocean the model results deviate strongly from the MODIS data (up to $90 \%$ ). The biases could be caused by several reasons which make a quantitative comparison difficult. In order to conduct a thorough quantitative evaluation of the model results with the satellite data, the model would have to include sampling of the data as seen from the satellite (e.g. taking into account the cloud cover and the specific satellite overpass times). This could not be done here. Furthermore, the uncertainty of the satellite data that can be quite large

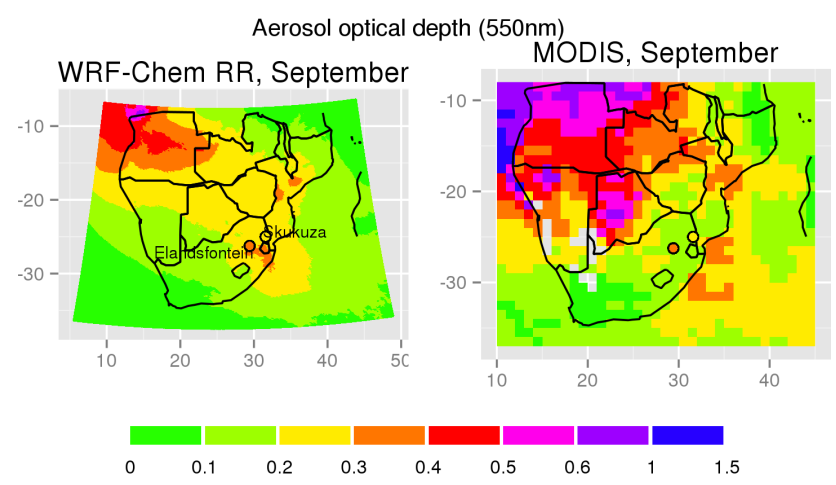

Figure 9. Comparison of modeled AOD with MODIS satellite observations, September 2010.

particularly for large AOD values (Ruiz-Arias et al., 2013) would have to be taken into account. This can also be seen in Fig. 9 showing ground-based AOD measurements from the AERONET network for comparison.

We therefore also compare modeled monthly mean aerosol optical depths with AERONET measurements at Skukuza, located in the Kruger National Park on the eastern border of South Africa, and Elandsfontein, located in the industrialized Highveld east of Johannesburg (Holben et al., 1998, see Fig. 1 for the location of the stations). Here, only measurements obtained under cloud-free conditions are used. Daily mean AODs are not available for every day from September 2010 to December 2010, with 10 missing days at Elandsfontein in September, 14 missing days at Skukuza in each October and November, and 19 missing days at Skukuza in December. The measured AODs at 500 and $675 \mathrm{~nm}$ are linearly interpolated to the AOD at $550 \mathrm{~nm}$, which is calculated by the model.

The mean AOD (Table 3) is higher at Elandsfontein, which is located closer to anthropogenic aerosol sources, than at Skukuza. AOD is modeled reasonably well at both stations and during most months. Measured (modeled) means at Elandsfontein amount to ca. 0.31 (0.32) in September, 0.40 (0.54) in October, $0.21(0.35)$ in November and $0.15(0.40)$ in December, and at Skukuza to ca. 0.30 (0.25) in September, $0.32(0.34)$ in October, $0.20(0.21)$ in November and 0.14 (0.14) in December. Overall, the comparisons of the model results with the AERONET AOD show a reasonably good performance of WRF-Chem in simulating the AOD at this location. The fairly good agreement of the model results with measurements close to anthropogenic sources (Elandsfontein) suggests that total energy-related anthropogenic aerosol emissions are at least within the correct order of magnitude.

\subsubsection{Particulate matter}

The model results are further compared with the measurements conducted at stations of the South African Weather 
Table 3. Monthly mean and mean bias of modeled and observed AOD, $\mathrm{PM}_{2.5}$ and $\mathrm{PM}_{10}$.

\begin{tabular}{|c|c|c|c|c|}
\hline Variable & Month & WRF-Chem mean & Measurements mean & Mean bias \\
\hline \multicolumn{5}{|c|}{ Elandsfontein } \\
\hline \multirow[t]{4}{*}{ AOD } & September & 0.32 & 0.31 & 0.01 \\
\hline & October & 0.54 & 0.40 & 0.14 \\
\hline & November & 0.35 & 0.21 & 0.14 \\
\hline & December & 0.40 & 0.15 & 0.25 \\
\hline \multicolumn{5}{|l|}{ Skukuza } \\
\hline \multirow{4}{*}{ AOD } & September & 0.25 & 0.30 & -0.05 \\
\hline & October & 0.34 & 0.32 & 0.02 \\
\hline & November & 0.21 & 0.20 & 0.01 \\
\hline & December & 0.14 & 0.14 & -0.0001 \\
\hline \multicolumn{5}{|l|}{ Secunda } \\
\hline \multirow{4}{*}{$\begin{array}{l}\mathrm{PM}_{10} \\
\left(\mu \mathrm{g} \mathrm{m}^{-3}\right)\end{array}$} & September & 49.17 & 143.56 & -94.39 \\
\hline & October & 51.45 & 68.72 & -17.27 \\
\hline & November & 38.10 & 38.52 & -0.42 \\
\hline & December & 32.41 & 38.55 & -6.41 \\
\hline \multirow{4}{*}{$\begin{array}{l}\mathrm{PM}_{2.5} \\
\left(\mu \mathrm{g} \mathrm{m}^{-3}\right)\end{array}$} & September & 45.03 & 46.49 & -1.46 \\
\hline & October & 48.30 & 25.94 & 22.36 \\
\hline & November & 35.53 & 16.42 & 19.11 \\
\hline & December & 30.16 & 17.52 & 12.64 \\
\hline \multicolumn{5}{|l|}{ Witbank } \\
\hline \multirow{4}{*}{$\begin{array}{l}\mathrm{PM}_{10} \\
\left(\mu \mathrm{gm}^{-3}\right)\end{array}$} & September & 51.96 & 76.88 & -24.92 \\
\hline & October & 47.18 & 39.95 & 7.23 \\
\hline & November & 34.47 & 22.30 & 12.17 \\
\hline & December & 43.35 & 28.82 & 14.53 \\
\hline \multirow{4}{*}{$\begin{array}{l}\mathrm{PM}_{2.5} \\
\left(\mu \mathrm{g} \mathrm{m}^{-3}\right)\end{array}$} & September & 46.33 & 36.34 & 9.99 \\
\hline & October & 42.97 & 22.19 & 20.18 \\
\hline & November & 31.00 & 13.37 & 17.63 \\
\hline & December & 39.54 & 17.28 & 22.26 \\
\hline \multicolumn{5}{|l|}{ Zamdela } \\
\hline \multirow{4}{*}{$\begin{array}{l}\mathrm{PM}_{2.5} \\
\left(\mu \mathrm{g} \mathrm{m}^{-3}\right)\end{array}$} & September & 48.69 & 36.94 & 11.75 \\
\hline & October & 51.56 & 34.89 & 16.67 \\
\hline & November & 36.02 & 28.65 & 7.37 \\
\hline & December & 35.01 & 29.00 & 6.01 \\
\hline
\end{tabular}

Service (see Sect. 2) from September 2010 to December 2010, including Secunda $\left(\mathrm{PM}_{10}\right.$ and $\left.\mathrm{PM}_{2.5}\right)$, Witbank $\left(\mathrm{PM}_{10}\right.$ and $\left.\mathrm{PM}_{2.5}\right)$ and Zamdela $\left(\mathrm{PM}_{2.5}\right)$; as presented in Table 3 (see Fig. 1 for the location of the stations).

Averaged over the whole modeling period and all stations, WRF-Chem underestimated $\mathrm{PM}_{10}$ by $-26 \%$ (observed: $58.42 \mu \mathrm{g} \mathrm{m}^{-3}$, modeled: $43.50 \mu \mathrm{g} \mathrm{m}^{-3}$ ), and overestimated $\mathrm{PM}_{2.5}$ by $51 \%$ (observed: $27.02 \mu \mathrm{g} \mathrm{m}^{-3}$, modeled: $40.84 \mu \mathrm{g} \mathrm{m}^{-3}$ ). This could indicate that the size-distribution of primary particles such as mineral dust assumed in the model for the emissions of these particles might be too small.

WRF-Chem underestimated the $\mathrm{PM}_{10}$ concentrations in September at Witbank up to $-66 \%$. It is biased positively in
October (6\%), November (31\%) and December (43\%). At Secunda, a slight negative bias is found during all 4 months, from $-32 \%$ in September to only $-1 \%$ in November. The $\mathrm{PM}_{2.5}$ concentrations are - given the large uncertainties and model deficiencies as discussed for BC in Sect. 3.2.3, such as the low quality of emission inventories - modeled reasonably well for September at all three stations, with the modeled values biased for Witbank $+28 \%$ and Zamdela $+32 \%$ and only biased by $-3 \%$ in Secunda. For October, November and December the modeled concentrations at Secunda and Witbank are positively biased, with both the modeled range of daily means and the median being higher than the measurements. 
The bias is smaller at Zamdela, especially during the wet season.

The biases might suggest that the different sources of PM might not be represented correctly in the emission data, or that the assumed particle size distributions are not representative for southern African conditions.

\subsection{Gaseous species at Welgegund}

To further assess the performance of WRF-Chem, results are compared with measurements at Welgegund (Fig. 7) for ozone $\left(\mathrm{O}_{3}\right)$, sulfur dioxide $\left(\mathrm{SO}_{2}\right)$, nitrogen oxides $\left(\mathrm{NO}+\mathrm{NO}_{2}=\mathrm{NO}_{x}\right)$ and carbon monoxide (CO). The statistics including bias and temporal correlation coefficients are summarized in Table 2.

WRF-Chem has a negative bias in $\mathrm{CO}(-31 \mathrm{ppb} /-15 \%$ in September, $-14 \mathrm{ppb} /-13 \%$ in December, $-18 \%$ overall) and ozone $(-8 \mathrm{ppb} /-15 \%$ in September, $-5 \mathrm{ppb} /-15 \%$ in December, $-19 \%$ overall). The modeled $\mathrm{SO}_{2}$ is in good agreement with the measurements (bias $-0.04 \mathrm{ppb},-2 \%$ ) in September, but overestimated in December (1.6 ppb, $+160 \%$ ). Averaged over the whole period the modeled bias in $\mathrm{SO}_{2}$ at Welgegund is $0.9 \mathrm{ppb}(65 \%)$. Likewise, the modeled $\mathrm{NO}_{x}$ is overestimated throughout the entire simulation period with biases ranging from $1.7 \mathrm{ppb}(56 \%)$ in September to $6.7 \mathrm{ppb}(270 \%)$ in December. The model bias of CO and $\mathrm{O}_{3}$ is rather similar throughout all modeled months, while that of $\mathrm{NO}_{x}$ and $\mathrm{SO}_{2}$ is much higher in December (wet season) than in September (dry season).

Particularly very high modeled $\mathrm{NO}_{x}$ values in December are probably related to very high emissions, which are higher than the maximum values found in the EDGAR HTAP emission inventory over Europe. This supports that emission inventories for Africa still have large uncertainties particularly for individual species and source regions.

In addition, we have compared model results for $\mathrm{NO}_{2}$ (tropospheric column) and CO (lowest model layer) with satellite data (not shown). These qualitative comparisons show that the emission hotspots seem to be in the right locations.

\subsection{Summary and conclusions from the model evaluation}

The evaluation of WRF-Chem with ground observations, satellite data and the comparison to reanalysis and model data has highlighted some points that need improvement but also showed that overall both meteorology, aerosols and gaseous species are simulated reasonably well during the dry season, given the large uncertainties in, for instance, the emission data or the lateral boundary conditions as observations are generally very sparse in this region. Concerning the meteorology, a bias in precipitation exists with precipitation amounts being overestimated by the model particularly during the wet season over the Indian Ocean between Madagascar and continental East Africa as well as in the ITCZ. The comparison of the model with measurement data obtained at the Welgegund measurement site confirms that precipitation amounts are mostly overestimated and that the beginning of the rainy season in the model is about 1 month too early (midSeptember instead of mid-October). Furthermore, the main modeled wind direction at Welgegund is shifted towards the north which directly affects the modeled transport of atmospheric pollutants from the Johannesburg-Pretoria area towards the measurement station.

As for the modeled $\mathrm{BC}$ concentration at Welgegund, it is biased low in comparison to the measurement data in the dry season. The main reasons for this underestimation are likely the shift in main wind direction in the model, as well as the modeled early beginning of the rainy season, likely leading to enhanced wet deposition. Both of these shortcomings are expected to result in less BC transported to the measurement station than shown by the observations. This shows the importance of capturing the observed meteorology with the model in addition to reasonable emission estimates. An evaluation of a large-scale model with only a few available comprehensive measurement stations is challenging and underlines the need for further comprehensive monitoring sites in southern Africa. Especially the lack of comprehensive measurement stations in the western part of South Africa makes the model evaluation challenging. The effort of setting up further monitoring sites is underway (see Sect. 5).

The reasonably good temporal correlation of the $\mathrm{BC}$ daily means time series with measurements suggests that the biomass burning emissions, with a 1-day resolution, capture the biomass burning events reasonably well. The comparison of measured AOD, $\mathrm{PM}_{10}, \mathrm{PM}_{2.5}$ with model results in nearsource regions further suggests that the total energy-related anthropogenic aerosol emissions in these regions seem to be within the correct order of magnitude. This might, however, not necessarily be true for individual species such as $\mathrm{NO}_{x}$.

Overall, the qualitative reasonably good results as well as the identification of plausible reasons for the low bias of modeled BC at Welgegund suggest that the model setup is suitable for a first assessment of the contribution of anthropogenic $\mathrm{BC}$ and co-emitted species to aerosol concentrations on a regional scale and their impact on meteorology.

In addition to the above-discussed uncertainties in the model, model parameterizations and model parameters such as assumed particle size-distributions might not be well suited for application in this region. We therefore consider the results of this study on the anthropogenic contribution to $\mathrm{BC}$ concentrations in southern Africa as a very first and rough estimate and as a potential basis for comparison with future studies using improved models and better input data. 


\section{Contribution of anthropogenic BC sources to aerosol loadings}

\subsection{Black Carbon}

\subsubsection{Near-surface concentrations}

The sensitivity run (S1) shows that anthropogenic emissions are the main contributors to $\mathrm{BC}$ loadings in many parts of the southern Africa (Fig. 10a). In September, anthropogenic $\mathrm{BC}$ contributes between 90 and $100 \%$ to the simulated $\mathrm{BC}$ loadings in the center of the industrialized and urban area around Johannesburg and Pretoria, and the contribution is similarly high in coastal areas (especially around Cape Town), which are generally more populated than the south-western inland areas. In these coastal regions, savannah fires do not contribute significantly to the BC concentrations compared with the northern part of the subcontinent. At Welgegund, the share of anthropogenic BC in September ranges between 80 and $90 \%$ (i.e. up to $5 \mu^{-3} \mathrm{~m}^{-3}$ in September and up to $2.5 \mu \mathrm{g} \mathrm{m}^{-3}$ in December). Energy-related anthropogenic emissions do not seem to play a large role in areas with strong biomass burning, where the share of $\mathrm{BC}$ concentrations caused by total anthropogenic emissions (60$70 \%$ ) is in the same range as the assumed fraction of anthropogenic biomass burning emissions (65\%). In December the anthropogenic portion of $\mathrm{BC}$ is up to $100 \%$ in an area covering most parts of eastern South Africa and Zimbabwe, including Welgegund. In coastal areas the results for December are similar to the September result.

\subsubsection{Vertical distribution}

The mean BC differences in September are analyzed further at two latitudinal cross sections displaying the vertical profile of BC (Fig. 11): a northern cross section averaged over the latitudes 14.25 to $12.75^{\circ} \mathrm{S}$, and a southern cross section averaged over 27.25 to $25.75^{\circ} \mathrm{S}$. In order to reduce the noise, the data have, in addition to the monthly averaging, also been binned into $45-\mathrm{km}$ bins consisting of three grid cells in the longitudinal direction. The vertical coordinate (pressure) is divided into 12 bins, each $50 \mathrm{hPa}$, the averaging time is 1 month. The northern cross section covers areas with strong biomass-burning emissions, and the southern cross section includes the Johannesburg-Pretoria megacity.

The cross sections show distinct differences between the two source regions of BC (Fig. 11a): in the northern domain, high $\mathrm{BC}$ concentrations of up to $0.5 \mu \mathrm{g} \mathrm{m}^{-3}$ are found up to ca. $500 \mathrm{hPa}$. It can be seen further that on average the plume does not rise much higher than $500 \mathrm{hPa}$, but is then rather transported out onto the South Atlantic Ocean. This is consistent with a persistent stably stratified 500-hPa layer described by Tyson and Preston-Whyte (2000). The cross section over the industrialized Highveld shows a different picture: the anthropogenic BC contribution decreases more rapidly with

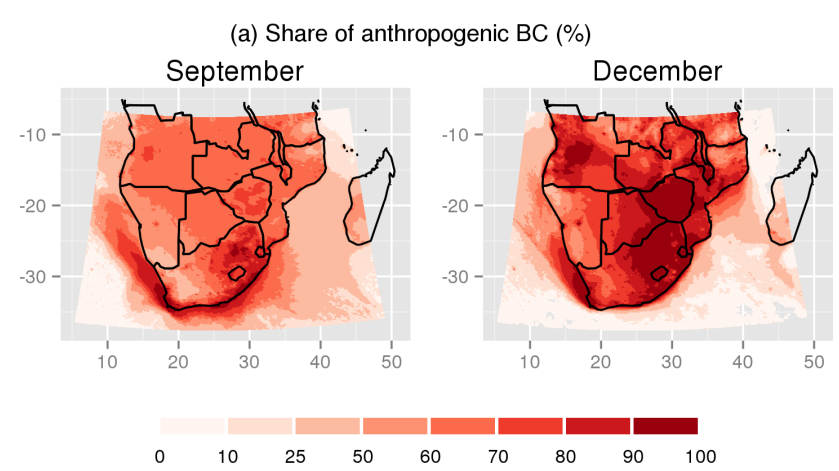

(b) Difference in AOD (550nm)

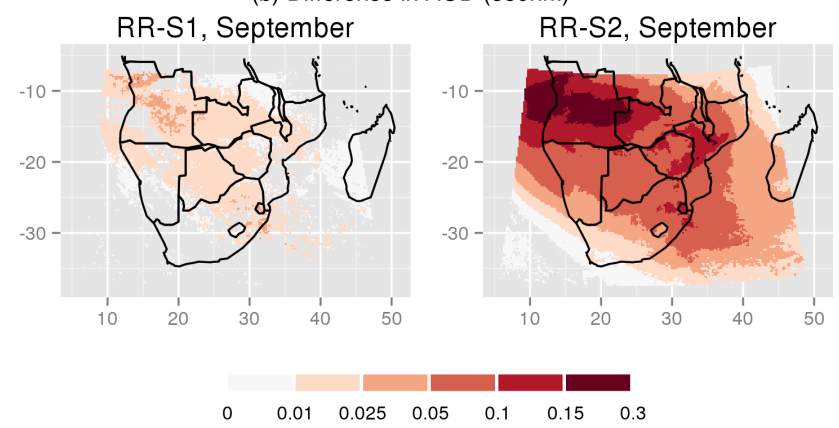

Figure 10. (a) Contribution of anthropogenic BC sources to $B C$ concentrations, (b) contribution of anthropogenic BC sources to AOD (left: contribution of anthropogenic BC only, right: contribution of anthropogenic BC and co-emitted aerosols). For (b), the model results have been interpolated to a lon-lat-grid of $0.2^{\circ} \times 0.2^{\circ}$, and only grid cells statistically significant at a confidence level of $95 \%$ are shown.

height, and the highest concentrations are found near the surface (the elevation of Pretoria is about $1300 \mathrm{~m}$ a.s.l.).

The anthropogenic contribution to $\mathrm{BC}$ concentrations ranges up to $90 \%$ in the urban core of the southern cross section (Fig. 11b). In particular in this highly industrialized area the anthropogenic contribution to BC loadings is large and dominates the modeled concentrations. This is important when assessing for instance the health impact of (anthropogenic) $\mathrm{BC}$. The share of anthropogenic $\mathrm{BC}$ ranges between 60 and $70 \%$ in the biomass-burning area, both at the surface and at higher layers.

\subsubsection{Biomass burning vs. energy-related emissions}

The total share of $\mathrm{BC}$ from biomass-burning emissions (natural and anthropogenic) is estimated from the sensitivity run $\mathrm{S} 1$ by scaling up the modeled $\mathrm{BC}$ concentrations by a factor of $100 \% / 35 \%=2.86$. The scaled concentrations are then compared to the reference run (RR). In the urban and industrialized areas (averaged over $1.5^{\circ} \times 1.5^{\circ}$ around the metropolitan area of Johannesburg and Pretoria), the estimated contribution of biomass-burning emissions to the total near-surface $\mathrm{BC}$ concentrations amounts up to $62 \%$ 
(a) BC concentration $\left(\mu \mathrm{g} / \mathrm{m}^{3}\right)$

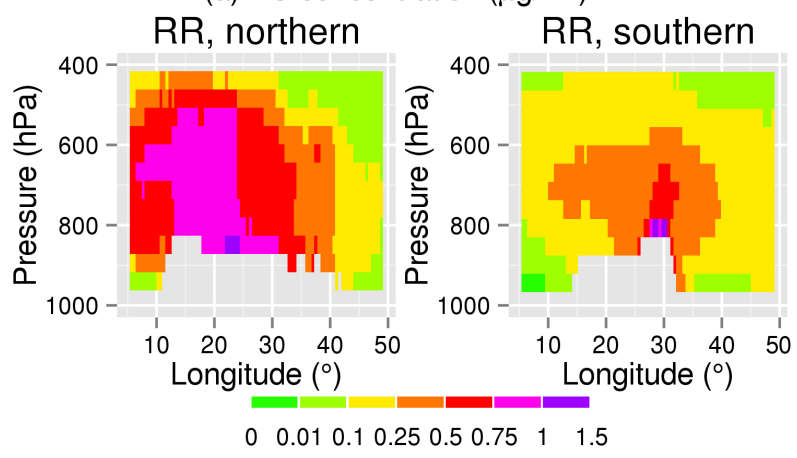

(b) Share of anthropogenic BC (\%)

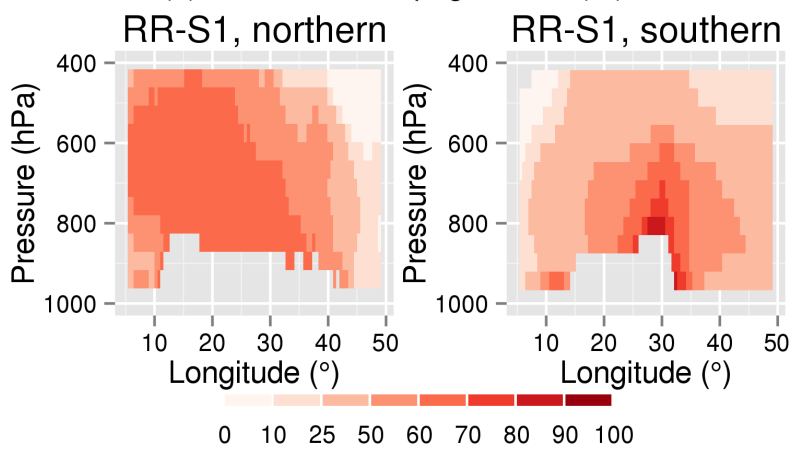

(c) Difference in heating rate $(\mathrm{K} / \mathrm{d})$

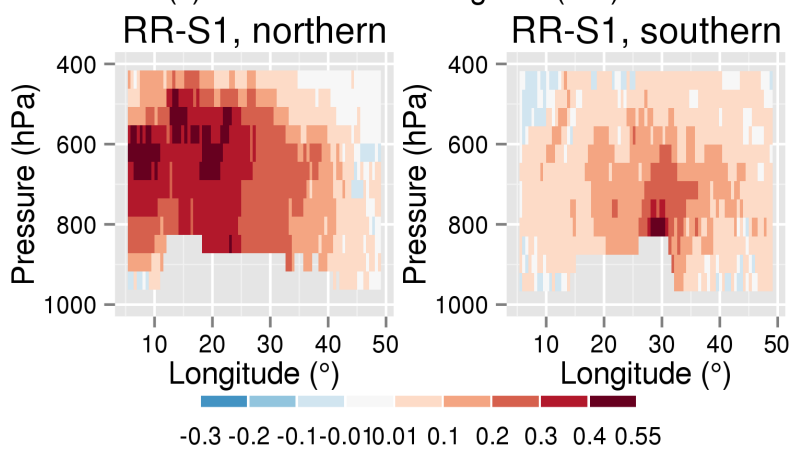

Figure 11. Vertical BC distribution (a), anthropogenic contribution to $\mathrm{BC}$ concentrations (b) and contribution of anthropogenic $\mathrm{BC}$ to atmospheric heating rates (c). All figures show the monthly mean results for September 2010.

(Fig. 12), but with much lower average values $(25 \%$ in September, $16 \%$ in October, $5 \%$ in November, $4 \%$ in December). The model results further suggest that the contribution of biomass burning to the total $\mathrm{BC}$ is much higher at Welgegund, with monthly averages of $57 \%$ in September, $44 \%$ in October, $16 \%$ in November and $10 \%$ in December, confirming the findings of Tiitta et al. (2014) that biomass burning plays an important role for the $\mathrm{BC}$ levels observed at Welgegund during the dry season.

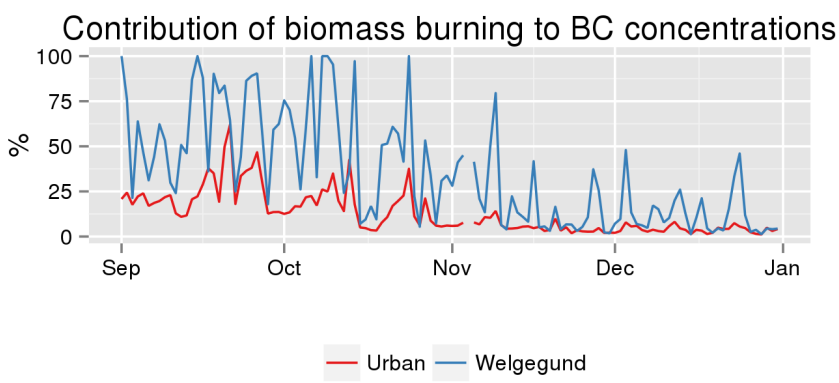

Figure 12. Estimated contribution of biomass burning emissions to $\mathrm{BC}$ concentrations in the Johannesburg-Pretoria urban area and at Welgegund.

\subsection{Particulate matter and aerosol optical depth}

$\mathrm{BC}$ particles are usually in the sub-micron size range (e.g., Petzold et al., 2005; Schwarz et al., 2008; Kondo et al., 2011) contributing only little to $\mathrm{PM}_{2.5}$ and $\mathrm{PM}_{10}$ as these are often dominated by other particle types. In the following, we therefore focus on the contribution of $\mathrm{BC}$ to $\mathrm{PM}_{1}$.

In September, the $\mathrm{PM}_{1}$ concentration modeled with WRFChem (not shown) reaches peak values of up to $55 \mu \mathrm{g} \mathrm{m}^{-3}$ around Johannesburg and Pretoria, and up to $30 \mu \mathrm{g} \mathrm{m}^{-3}$ in areas of highest biomass-burning emissions. In the northern part of the continent and in the surroundings of Johannesburg and Pretoria, modeled concentrations range mostly in between 10 and $15 \mu \mathrm{g} \mathrm{m}^{-3}$. In December the modeled $\mathrm{PM}_{1}$ concentrations are highest around Johannesburg and Pretoria with values up to $30 \mu \mathrm{g} \mathrm{m}^{-3}$.

In the northern areas dominated by biomass burning the contribution of anthropogenic BC to the modeled (nearsurface) $\mathrm{PM}_{1}$ concentration in September ranges between 5 and $7.5 \%$ with some spatial variations. The contribution of the modeled anthropogenic $\mathrm{BC}$ to $\mathrm{PM}_{1}$ ranges up to 10 to $15 \%$ in the surroundings of the Johannesburg-Pretoria area and between 7.5 and $10 \%$ at Welgegund. Averaged over the whole urban area around Johannesburg and Pretoria, the mean contribution of anthropogenic BC to $\mathrm{PM}_{1}$ in September amounts to $6 \%$.

The measured contribution of (total) $\mathrm{BC}$ to $\mathrm{PM}_{1}$ at Welgegund is $13 \%$ (average over one year, Tiitta et al., 2014). This value is not directly comparable to the model result for September but within a similar range as that calculated by the model for anthropogenic BC (10\%). Despite the underestimation of the absolute $\mathrm{BC}$ concentrations by the model both model results and measurements suggest that anthropogenic $\mathrm{BC}$ is an important contributor to $\mathrm{PM}_{1}$. This is especially important when assessing the health effect of PM.

When also accounting for the co-emitted species (OC and $\mathrm{SO}_{2}$ ), the modeled contribution of both $\mathrm{BC}$ and co-emitted species to $\mathrm{PM}_{1}$ in September is highest around Johannesburg and Pretoria amounting up to $60 \%$, underlining the impor- 
tance of co-emitted species when assessing the contribution of anthropogenic $\mathrm{BC}$ sources to $\mathrm{PM}_{1}$ concentrations.

The difference in AOD between the reference run and the sensitivity simulation S1 (Fig. 10b) shows a similar spatial variability in September as $\mathrm{PM}_{1}$. Only those grid cells with the differences significantly different from 0 at a $95 \%$ confidence level are shown. The differences in AOD range between 5 and $10 \%$ in both areas of strong biomass burning and over the industrialized Highveld. In December, the differences in AOD are not statistically significant and longer model integrations would be needed to improve the signalto-noise ratio.

When also accounting for co-emitted species (S2) the contribution to AOD ranges up to $0.3(50 \%)$ in the northwest of the model domain. The contribution decreases towards the southeast, with an island of high contribution to AOD near Pretoria and Johannesburg (up to 0.15). In December, the total anthropogenic contribution of BC and co-emitted species to AOD is highest over Johannesburg and Pretoria with a maximum of up to 0.3 .

The increase in AOD results in a reduction of incoming solar radiation at the surface or surface dimming (not shown), but the integration time was too short for the results to be statistically significant. This result is, however, consistent with what has been reported in the literature (e.g. Tummon et al., 2010).

\subsection{Contribution of anthropogenic $\mathrm{BC}$ to atmospheric heating rates}

The vertical heating rate difference $(\Delta \mathrm{HR}$, only the shortwave contribution is considered here) is assessed for September along the same cross sections discussed above (Fig. 11c). Atmospheric heating by anthropogenic BC in the model reaches up to ca. $0.7 \mathrm{Kday}^{-1}$ around $600 \mathrm{hPa}$ in the northern cross section and near the surface around Johannesburg and Pretoria in the southern cross section. The strongest change in heating rates are spread vertically up to $600 \mathrm{hPa}$ in the northern cross section, because emissions from biomass burning are efficiently transported to these heights in the model. In contrast, the maximum changes in heating rates caused by anthropogenic $\mathrm{BC}$ in the southern cross section are found close to the surface over the industrialized Highveld.

These model results suggest that $\mathrm{OC}$ and $\mathrm{SO}_{2}$ co-emitted with anthropogenic BC play only a minor role for the heating rates compared with $\mathrm{BC}$ itself. The peak values in heating rates caused by anthropogenic $\mathrm{BC}$ and co-emissions (S2) amount to about $0.7 \mathrm{Kday}^{-1}$, which are in the same range as modeled for anthropogenic $\mathrm{BC}$ alone (S1).

\section{Conclusions}

This study presents and evaluates a model setup for studying air chemistry and aerosol processes and their impacts in southern Africa. In addition, a consistency check on the emission input data is done by comparing PM measurements with the model results in urban regions that are expected to be dominated by anthropogenic emissions. It then assesses the contribution of anthropogenic BC and co-emitted species to aerosol concentrations ( $\mathrm{BC}$ and $\mathrm{PM}_{1}$ ) and to aerosol optical depth, and assesses the impact of $\mathrm{BC}$ sources on atmospheric heating rates.

The evaluation of the WRF-Chem model applied over southern Africa shows that the main features of the meteorology such as temperature and sea-level pressure are modeled reasonably well, but some parameters, such as precipitation, are more problematic. Precipitation is very challenging to model: for example, Crétat et al. (2011) show that WRF has difficulties in reproducing observed precipitation amounts and patterns over southern Africa for a variety of different physics options.

Black carbon monthly mean concentrations are underestimated at Welgegund in September and October by ca. $50 \%$. Reasons contributing to the underestimation during the dry season are likely the biases in the modeled meteorological variables resulting in less than observed $\mathrm{BC}$ transported from the industrial source regions to Welgegund. These are in particular the shifted wind direction in September, the early beginning of the rainy season in the model in October and the overestimation of precipitation amounts. The importance of the wind direction bias for the $\mathrm{BC}$ bias is supported by the fact that the amplitude of the modeled monthly mean BC concentration is closer to the measured means when comparing to the results for an equivalent location (same distance from the urban and industrialized areas of Johannesburg and Pretoria as Welgegund but downwind of the modeled main wind direction). In November and in December the monthly mean BC concentrations at Welgegund are small and in reasonably good agreement with the measurements.

Besides the modeled meteorology, the high uncertainties in the emission inventories, the choice of chemical boundary conditions or uncertainties and limitations in the representations of important processes in the model (e.g. the particle size distribution, the parametrization of convection or the boundary layer) are likely to contribute significantly to the model biases in $\mathrm{BC}$ concentrations.

The modeled BC concentrations at Welgegund have a temporal correlation with measurements of 0.62 and 0.67 in September and October, respectively. This reasonable correlation can be attributed to the well-modeled day-to-day variability of the meteorology. This also suggests that the temporal resolution and pattern of the biomass burning emissions, which contribute significantly to the total $\mathrm{BC}$ at Welgegund, are a reasonable estimate of the real biomass burning emissions.

The comparison of the model results for AOD, $\mathrm{PM}_{2.5}$, and $\mathrm{PM}_{10}$ with AERONET data and observations in the industrialized Highveld and Vaal triangle region, as well as the model qualitatively capturing the geographical pattern of the AOD 
retrieved from MODIS satellite data, suggests that the magnitudes of the energy-related anthropogenic aerosol emissions used here (EDGAR HTAP) are, despite the generally low quality of emissions inventories for South Africa, a reasonable first estimate of the emissions. This is, however, not necessarily true for individual species such as $\mathrm{NO}_{x}$ or other source regions.

Two large source regions for anthropogenic BC are the industrialized and urban areas on the South African Highveld around Johannesburg and Pretoria (including the Mpumalanga industrial Highveld and the Vaal Triangle), and areas of large-scale biomass burning in the dry season. These are also the areas where the modeled $\mathrm{BC}$ concentrations are the highest on the subcontinent. These concentrations are strongly influenced by anthropogenic BC sources contributing up to $100 \%$ in the industrialized and urban areas around Johannesburg and Pretoria both during the dry and the wet season. Biomass burning BC contributes only little to the total BC modeled in the area around Pretoria and Johannesburg but contributions increase significantly towards the outskirts of the area, e.g. at Welgegund.

An analysis of the atmospheric heating rates shows a slight surface heating over the industrialized South African Highveld (S1) that might be largely canceled by cooling due to surface dimming caused mainly by co-emitted species (S2). Black carbon from biomass burning at higher layers of the atmosphere leads to increased atmospheric heating rates and local warming in the lower and middle troposphere, possibly impacting the atmospheric stability in this region.

The high computational cost of WRF-Chem at $15 \mathrm{~km}$ resolution over the entire southern African subcontinent did not allow for long-term simulations. Instead, it was chosen to simulate only 4 months from September 2010 to December 2010, which include parts of the dry season, the wet season as well as the transition period. Because of the strong convection during the wet season, the signal-to-noise ratio of the model results is low particularly in December. Integrating over longer time intervals, spanning several seasons or years, would help increase the signal-to-noise ratio, thus increasing the robustness of the obtained results. Possible refinements of the model include a more detailed specification of the particle size distributions used for the emissions, ideally based on long-term measurements of the aerosol size-distribution in different source regions (natural and anthropogenic aerosols). Furthermore, future studies could assess whether a nudging to meteorological observational/reanalysis data would improve the model results, or the usage of urban parametrizations for improving the results for urban areas. The latter would, however, most likely require changing the urban scheme's parameters, as these schemes have not been developed for African cities.

For deepening the analysis of the different impacts of anthropogenic $\mathrm{BC}$ it is crucial to have good observational data, e.g. for $\mathrm{BC}$ and particulate matter, vertical profiles of temperature and humidity. Furthermore, long-term measurements of $\mathrm{BC}$ and other aerosols are not only crucial for improving aerosol and chemistry modeling over southern Africa, but also serve for monitoring air quality and assessing air quality management plans and further identifying main sources within the different source categories. So far, only few measurements existed especially of fine particulate matter and $\mathrm{BC}$. However, further monitoring of $\mathrm{BC}$ concentrations has recently been initiated: in 2012, continuous BC measurements using the MAAP have commenced at the Secunda, Witbank and Zamdela stations. The network expanded ( $\mathrm{Au}-$ gust 2013) to include additional monitoring stations in the Vaal Triangle operated by the South African Weather Service (SAWS). In addition, aethalometers have been installed in SAWS owned stations in the Karoo and Bojanala areas (September 2014).

Reliable emission inventories with a high temporal and spatial resolution are important in order to improve the modeling of aerosols and air chemistry. More research efforts are needed to create such inventories. For example, further model simulations could aim at analyzing contributions of individual source categories to the modeled BC concentrations. For this, tagging of the individual emitted species would be needed. There is also a need for weekly and diurnal emission profiles as well as the vertical distribution including, for instance, the stack height of important point sources, or the contribution of the different sources within one source category. This is particularly the case for the Pretoria and Johannesburg area, and the industrialized areas in the Mpumalanga Highveld and the Vaal Triangle, where further growth is expected and air pollution is already a recognized problem.

Acknowledgements. We acknowledge the UK Met Office for the supply of its Global Radiosonde Data through the British Atmospheric Data Centre. The MODIS AOD data used in this study were produced with the Giovanni online data system, developed and maintained by the NASA GES DISC. All model simulations with WRF-Chem were performed at the high performance cluster computer of the Potsdam Institute for Climate Impact Research (PIK). For creating figures, the open-source software R and the openair-package (Carslaw, 2014; Carslaw and Ropkins, 2012) have been used.

Edited by: V.-M. Kerminen

\section{References}

Beukes, J. P., Vakkari, V., Van Zyl, P. G., Venter, A. D., Josipovic, M., Jaars, K., Tiitta, P., Laakso, H., Kulmala, M., Worsnop, D., Pienaar, J. J., Järvinen, E., Chellapermal, R., Ignatius, K., Maalick, Z., Cesnulyte, V., Ripamonti, G., Laban, T. L., Skrabalova, L., du Toit, M., Virkkula, A., and Laakso, L.: Source region plume characterisation of the interior of South Africa, as measured at Welgegund, Clean Air J., 23, 7-10, 2013.

Bond, T. C., Doherty, S. J., Fahey, D. W., Forster, P. M., Berntsen, T., DeAngelo, B. J., Flanner, M. G., Ghan, S., Kärcher, B., Koch, 
D., Kinne, S., Kondo, Y., Quinn, P. K., Sarofim, M. C., Schultz, M. G., Schulz, M., Venkataraman, C., Zhang, H., Zhang, S., Bellouin, N., Guttikunda, S. K., Hopke, P. K., Jacobson, M. Z., Kaiser, J. W., Klimont, Z., Lohmann, U., Schwarz, J. P., Shindell, D., Storelvmo, T., Warren, S. G., and Zender, C. S.: Bounding the role of black carbon in the climate system: A scientific assessment, J. Geophys. Res.-Atmos., 118, 5380-5552, doi:10.1002/jgrd.50171, 2013.

Cao, G., Giambelluca, T. W., Stevens, D. E., and Schroeder, T. A.: Inversion Variability in the Hawaiian Trade Wind Regime, J. Climate, 20, 1145-1160, doi:10.1175/jcli4033.1, 2007.

Cappa, C. D., Onasch, T. B., Massoli, P., Worsnop, D. R., Bates, T. S., Cross, E. S., Davidovits, P., Hakala, J., Hayden, K. L., Jobson, B. T., Kolesar, K. R., Lack, D. A., Lerner, B. M., Li, S. M., Mellon, D., Nuaaman, I., Olfert, J. S., Petaja, T., Quinn, P. K., Song, C., Subramanian, R., Williams, E. J., and Zaveri, R. A.: Radiative absorption enhancements due to the mixing state of atmospheric black carbon, Science, 337, 1078-1081, doi:10.1126/science.1223447, 2012.

Cappa, C. D., Onasch, T. B., Massoli, P., Worsnop, D. R., Bates, T. S., Cross, E. S., Davidovits, P., Hakala, J., Hayden, K. L., Jobson, B. T., Kolesar, K. R., Lack, D. A., Lerner, B. M., Li, S. M., Mellon, D., Nuaaman, I., Olfert, J. S., Petaja, T., Quinn, P. K., Song, C., Subramanian, R., Williams, E. J., and Zaveri, R. A.: Response to comment on "Radiative absorption enhancements due to the mixing state of atmospheric black carbon", Science, 339, 393, doi:10.1126/science.1230260, 2013.

Carslaw, D. C.: The openair manual - open-source tools for analysing air pollution data, Manual for version 1.1-4, King's College London, London, UK, 2014.

Carslaw, D. C. and Ropkins, K.: openair - An R package for air quality data analysis, Environ. Model. Softw., 27-28, 52-61, doi:10.1016/j.envsoft.2011.09.008, 2012.

Crétat, J., Pohl, B., Richard, Y., and Drobinski, P.: Uncertainties in simulating regional climate of Southern Africa: sensitivity to physical parameterizations using WRF, Clim. Dynam., 38, 613634, doi:10.1007/s00382-011-1055-8, 2011.

Dee, D. P., Uppala, S. M., Simmons, A. J., Berrisford, P., Poli, P., Kobayashi, S., Andrae, U., Balmaseda, M. A., Balsamo, G., Bauer, P., Bechtold, P., Beljaars, A. C. M., van de Berg, L., Bidlot, J., Bormann, N., Delsol, C., Dragani, R., Fuentes, M., Geer, A. J., Haimberger, L., Healy, S. B., Hersbach, H., Hólm, E. V., Isaksen, L., Kållberg, P., Köhler, M., Matricardi, M., McNally, A. P., Monge-Sanz, B. M., Morcrette, J. J., Park, B. K., Peubey, C., de Rosnay, P., Tavolato, C., Thépaut, J. N., and Vitart, F.: The ERA-Interim reanalysis: configuration and performance of the data assimilation system, Q. J. Roy. Meteorol. Soc., 137, 553597, doi:10.1002/qj.828, 2011.

Dentener, F., Kinne, S., Bond, T., Boucher, O., Cofala, J., Generoso, S., Ginoux, P., Gong, S., Hoelzemann, J. J., Ito, A., Marelli, L., Penner, J. E., Putaud, J.-P., Textor, C., Schulz, M., van der Werf, G. R., and Wilson, J.: Emissions of primary aerosol and precursor gases in the years 2000 and 1750 prescribed data-sets for AeroCom, Atmos. Chem. Phys., 6, 4321-4344, doi:10.5194/acp-64321-2006, 2006.

Emmons, L. K., Walters, S., Hess, P. G., Lamarque, J.-F., Pfister, G. G., Fillmore, D., Granier, C., Guenther, A., Kinnison, D., Laepple, T., Orlando, J., Tie, X., Tyndall, G., Wiedinmyer, C., Baughcum, S. L., and Kloster, S.: Description and evaluation of the Model for Ozone and Related chemical Tracers, version 4 (MOZART-4), Geosci. Model Dev., 3, 43-67, doi:10.5194/gmd3-43-2010, 2010.

Fast, J. D., Gustafson, W. I., Easter, R. C., Zaveri, R. A., Barnard, J. C., Chapman, E. G., Grell, G. A., and Peckham, S. E.: Evolution of ozone, particulates, and aerosol direct radiative forcing in the vicinity of Houston using a fully coupled meteorology-chemistry-aerosol model, J. Geophys. Res., 111, D21305, doi:10.1029/2005jd006721, 2006.

Freiman, M. T. and Piketh, S. J.: Air Transport into and out of the Industrial Highveld Region of South Africa, J. Appl. Meteorol., 42, 994-1002, doi:10.1175/15200450(2003)042<0994:atiaoo>2.0.co;2, 2003.

Goldberg, E. D.: Black Carbon in the Environment - Properties and Distribution, John Wiley \& Sons Inc., New York, 216 p., 1985.

Grell, G. A., Peckham, S. E., Schmitz, R., McKeen, S. A., Frost, G., Skamarock, W. C., and Eder, B.: Fully coupled "online" chemistry within the WRF model, Atmos. Environ., 39, 6957-6975, doi:10.1016/j.atmosenv.2005.04.027, 2005.

Grell, G., Freitas, S. R., Stuefer, M., and Fast, J.: Inclusion of biomass burning in WRF-Chem: impact of wildfires on weather forecasts, Atmos. Chem. Phys., 11, 5289-5303, doi:10.5194/acp11-5289-2011, 2011.

Guenther, A., Karl, T., Harley, P., Wiedinmyer, C., Palmer, P. I., and Geron, C.: Estimates of global terrestrial isoprene emissions using MEGAN (Model of Emissions of Gases and Aerosols from Nature), Atmos. Chem. Phys., 6, 3181-3210, doi:10.5194/acp-63181-2006, 2006.

Heidinger, A. K., Foster, M. J., Walther, A., and Zhao, X.: The Pathfinder Atmospheres-Extended AVHRR Climate Dataset, B. Am. Meteorol. Soc., 95, 909-922, doi:10.1175/bams-d-1200246.1, 2014

Hodnebrog, O., Myhre, G., and Samset, B. H.: How shorter black carbon lifetime alters its climate effect, Nature Comm., 5, 5065, doi:10.1038/ncomms6065, 2014.

Holben, B. N., Eck, T. F., Slutsker, I., Tanré, D., Buis, J. P., Setzer, A., Vermote, E., Reagan, J. A., Kaufman, Y. J., Nakajima, T., Lavenu, F., Jankowiak, I., and Smirnov, A.: AERONET - A Federated Instrument Network and Data Archive for Aerosol Characterization, Remote Sens. Environ., 66, 1-16, doi:10.1016/s0034-4257(98)00031-5, 1998.

Huffman, G. J., Adler, R. F., Morrissey, M. M., Bolvin, D. T., Curtis, S., Joyce, R., McGavock, B., and Susskind, J.: Global Precipitation at One-Degree Daily Resolution from Multisatellite Observations, J. Hydrometeorol., 2, 36-50, doi:10.1175/15257541(2001)002<0036:gpaodd>2.0.co;2, 2001.

Huffman, G. J., Bolvin, D. T., Nelkin, E. J., Wolff, D. B., Adler, R. F., Gu, G., Hong, Y., Bowman, K. P., and Stocker, E. F.: The TRMM Multisatellite Precipitation Analysis (TMPA): QuasiGlobal, Multiyear, Combined-Sensor Precipitation Estimates at Fine Scales, J. Hydrometeorol., 8, 38-55, doi:10.1175/jhm560.1, 2007.

Hyvärinen, A.-P., Vakkari, V., Laakso, L., Hooda, R. K., Sharma, V. P., Panwar, T. S., Beukes, J. P., van Zyl, P. G., Josipovic, M., Garland, R. M., Andreae, M. O., Pöschl, U., and Petzold, A.: Correction for a measurement artifact of the Multi-Angle Absorption Photometer (MAAP) at high black carbon mass concentration levels, Atmos. Meas. Tech., 6, 81-90, doi:10.5194/amt-681-2013, 2013. 
Jaars, K., Beukes, J. P., van Zyl, P. G., Venter, A. D., Josipovic, M., Pienaar, J. J., Vakkari, V., Aaltonen, H., Laakso, H., Kulmala, M., Tiitta, P., Guenther, A., Hellén, H., Laakso, L., and Hakola, H.: Ambient aromatic hydrocarbon measurements at Welgegund, South Africa, Atmos. Chem. Phys., 14, 7075-7089, doi:10.5194/acp-14-7075-2014, 2014.

Janssen, N. A. H., Gerlofs-Nijland, M. E., Lanki, T., Salonen, R. O., Cassee, F., Hoek, G., Fischer, P., Brunekreef, B., and Krzyzanowski, M.: Health effects of black carbon, World Health Organization (WHO), Copenhagen, Denmark, 2012.

Janssens-Maenhout, G., Dentener, F., van Aardenne, J., Monni, S., Pagliari, V., Orlandini, L., Klimont, Z., Kurokawa, J., Akimoto, H., Ohara, T., Wankmüller, R., Battye, B., Grano, D., Zuber, A., and Keating, T.: EDGAR-HTAP: a harmonized gridded air pollution emission dataset based on national inventories, European Commission, Joint Research Centre, Institute for Environment and Sustainability, Luxemburg, 2012.

Kondo, Y., Oshima, N., Kajino, M., Mikami, R., Moteki, N., Takegawa, N., Verma, R. L., Kajii, Y., Kato, S., and Takami, A.: Emissions of black carbon in East Asia estimated from observations at a remote site in the East China Sea, J. Geophys. Res.Atmos., 116, D16201, doi:10.1029/2011JD015637, 2011.

Laakso, L., Laakso, H., Aalto, P. P., Keronen, P., Petäjä, T., Nieminen, T., Pohja, T., Siivola, E., Kulmala, M., Kgabi, N., Molefe, M., Mabaso, D., Phalatse, D., Pienaar, K., and Kerminen, V.-M.: Basic characteristics of atmospheric particles, trace gases and meteorology in a relatively clean Southern African Savannah environment, Atmos. Chem. Phys., 8, 4823-4839, doi:10.5194/acp-8-4823-2008, 2008.

Laakso, L., Vakkari, V., Virkkula, A., Laakso, H., Backman, J., Kulmala, M., Beukes, J. P., van Zyl, P. G., Tiitta, P., Josipovic, M., Pienaar, J. J., Chiloane, K., Gilardoni, S., Vignati, E., Wiedensohler, A., Tuch, T., Birmili, W., Piketh, S., Collett, K., Fourie, G. D., Komppula, M., Lihavainen, H., de Leeuw, G., and Kerminen, V.-M.: South African EUCAARI measurements: seasonal variation of trace gases and aerosol optical properties, Atmos. Chem. Phys., 12, 1847-1864, doi:10.5194/acp-12-1847-2012, 2012.

Laakso, L., Merikanto, J., Vakkari, V., Laakso, H., Kulmala, M., Molefe, M., Kgabi, N., Mabaso, D., Carslaw, K. S., Spracklen, D. V., Lee, L. A., Reddington, C. L., and Kerminen, V.-M.: Boundary layer nucleation as a source of new $\mathrm{CCN}$ in savannah environment, Atmos. Chem. Phys., 13, 1957-1972, doi:10.5194/acp13-1957-2013, 2013.

Lack, D. A., Langridge, J. M., Bahreini, R., Cappa, C. D., Middlebrook, A. M., and Schwarz, J. P.: Brown carbon and internal mixing in biomass burning particles, P. Natl. Acad. Sci. USA, 109, 14802-14807, doi:10.1073/pnas.1206575109, 2012.

Lourens, A. S., Beukes, J. P., Van Zyl, P. G., Fourie, G. D., Burger, J. W., Pienaar, J. J., Read, C. E., and Jordaan, J. H.: Spatial and temporal assessment of gaseous pollutants in the Highveld of South Africa, S. Afr. J. Sci., 107, 269, doi:10.4102/sajs.v107i1/2.269, 2011.

Lourens, A. S. M., Butler, T. M., Beukes, J. P., Van Zyl, P. G., Beirle, S., Wagner, T. K., Heue, K.-P., Pienaar, J. J., Fourie, G. D., and Lawrence, M. G.: Re-evaluating the $\mathrm{NO}_{2}$ hotspot over the South African Highveld, S. Afr. J. Sci., 108, 1146, doi:10.4102/sajs.v108i11/12.1146, 2012.

LRTAP-Wiki: HTAP harmonized emissions database 2006-2010: available at: http://iek8wikis.iek.fz-juelich.de/HTAPWiki/WP1. 1?highlight $=\% 28 \% 28 \mathrm{WP} 1.1 \% 29 \% 29$ (last access: 1 December 2014), 2014.

MetOffice Global Radiosonde Data: available at: http://catalogue. ceda.ac.uk/uuid/f2afaf808b61394b78bd342ff068c8cd (last access: 1 December 2014), 2006.

Minsenis, C. and Zhang, Y.: An examination of sensitivity of WRF/Chem predictions to physical parameterizations, horizontal grid spacing, and nesting options, Atmos. Res., 97, 315-334, doi:10.1016/j.atmosres.2010.04.005, 2010.

Ogren, J. A. and Charlson, R. J.: Elemental carbon in the atmosphere: cycle and lifetime, Tellus B, 35B, 241-254, doi:10.1111/j.1600-0889.1983.tb00027.x, 1983.

Petäjä, T., Vakkari, V., Pohja, T., Nieminen, T., Laakso, H., Aalto, P. P., Keronen, P., Siivola, E., Kerminen, V.-M., Kulmala, M., and Laakso, L.: Transportable Aerosol Characterization Trailer with Trace Gas Chemistry: Design, Instruments and Verification, Aerosol Air Qual. Res., 13, 421-435, doi:10.4209/aaqr.2012.08.0207, 2013.

Petzold, A., Gysel, M., Vancassel, X., Hitzenberger, R., Puxbaum, H., Vrochticky, S., Weingartner, E., Baltensperger, U., and Mirabel, P.: On the effects of organic matter and sulphurcontaining compounds on the $\mathrm{CCN}$ activation of combustion particles, Atmos. Chem. Phys., 5, 3187-3203, doi:10.5194/acp-53187-2005, 2005.

Petzold, A., Ogren, J. A., Fiebig, M., Laj, P., Li, S.-M., Baltensperger, U., Holzer-Popp, T., Kinne, S., Pappalardo, G., Sugimoto, N., Wehrli, C., Wiedensohler, A., and Zhang, X.-Y.: Recommendations for reporting "black carbon" measurements, Atmos. Chem. Phys., 13, 8365-8379, doi:10.5194/acp-13-83652013, 2013.

Ramanathan, V. and Carmichael, G.: Global and regional climate changes due to black carbon, Nat. Geosci., 1, 221-227, doi:10.1038/ngeo156, 2008.

Remer, L. A., Kaufman, Y. J., Tanré, D., Mattoo, S., Chu, D. A., Martins, J. V., Li, R. R., Ichoku, C., Levy, R. C., Kleidman, R. G., Eck, T. F., Vermote, E., and Holben, B. N.: The MODIS Aerosol Algorithm, Products, and Validation, J. Atmos. Sci., 62, 947-973, doi:10.1175/jas3385.1, 2005.

Reynolds, R. W., Smith, T. M., Liu, C., Chelton, D. B., Casey, K. S., and Schlax, M. G.: Daily High-Resolution-Blended Analyses for Sea Surface Temperature, J. Climate, 20, 5473-5496, doi:10.1175/2007jcli1824.1, 2007.

Rienecker, M. M., Suarez, M. J., Gelaro, R., Todling, R., Bacmeister, J., Liu, E., Bosilovich, M. G., Schubert, S. D., Takacs, L., Kim, G.-K., Bloom, S., Chen, J., Collins, D., Conaty, A., da Silva, A., Gu, W., Joiner, J., Koster, R. D., Lucchesi, R., Molod, A., Owens, T., Pawson, S., Pegion, P., Redder, C. R., Reichle, R., Robertson, F. R., Ruddick, A. G., Sienkiewicz, M., and Woollen, J.: MERRA: NASA's Modern-Era Retrospective Analysis for Research and Applications, J. Climate, 24, 3624-3648, doi:10.1175/jcli-d-11-00015.1, 2011.

Ruiz-Arias, J. A., Dudhia, J., Gueymard, C. A., and Pozo-Vázquez, D.: Assessment of the Level-3 MODIS daily aerosol optical depth in the context of surface solar radiation and numerical weather modeling, Atmos. Chem. Phys., 13, 675-692, doi:10.5194/acp-13-675-2013, 2013.

Ruti, P. M., Williams, J. E., Hourdin, F., Guichard, F., Boone, A., Van Velthoven, P., Favot, F., Musat, I., Rummukainen, M., Domínguez, M., Gaertner, M. Á., Lafore, J. P., Losada, T., Ro- 
driguez de Fonseca, M. B., Polcher, J., Giorgi, F., Xue, Y., Bouarar, I., Law, K., Josse, B., Barret, B., Yang, X., Mari, C., and Traore, A. K.: The West African climate system: a review of the AMMA model inter-comparison initiatives, Atmos. Sci. Lett., 12, 116-122, doi:10.1002/asl.305, 2011.

Samset, B. H., Myhre, G., Herber, A., Kondo, Y., Li, S.-M., Moteki, N., Koike, M., Oshima, N., Schwarz, J. P., Balkanski, Y., Bauer, S. E., Bellouin, N., Berntsen, T. K., Bian, H., Chin, M., Diehl, T., Easter, R. C., Ghan, S. J., Iversen, T., Kirkevåg, A., Lamarque, J.-F., Lin, G., Liu, X., Penner, J. E., Schulz, M., Seland, Ø., Skeie, R. B., Stier, P., Takemura, T., Tsigaridis, K., and Zhang, K.: Modelled black carbon radiative forcing and atmospheric lifetime in AeroCom Phase II constrained by aircraft observations, Atmos. Chem. Phys., 14, 12465-12477, doi:10.5194/acp14-12465-2014, 2014.

Schmale, J., Shindell, D., von Schneidemesser, E., Chabay, I., and Lawrence, M.: Air pollution: clean up our skies, Nature, 515, 335-337, doi:10.1038/515335a, 2014.

Schwarz, J. P., Gao, R. S., Spackman, J. R., Watts, L. A., Thomson, D. S., Fahey, D. W., Ryerson, T. B., Peischl, J., Holloway, J. S., Trainer, M., Frost, G. J., Baynard, T., Lack, D. A., de Gouw, J. A., Warneke, C., and Del Negro, L. A.: Measurement of the mixing state, mass, and optical size of individual black carbon particles in urban and biomass burning emissions, Geophys. Res. Lett., 35, L13810, doi:10.1029/2008GL033968, 2008.

Senatsverwaltung für Stadtentwicklung und Umwelt: Jahresübersicht der Luftqualität 2012, available at: http://www.stadtentwicklung.berlin.de/umwelt/luftqualitaet/ de/jahresuebersicht/luft_2012/verkehr.shtml (last access: 19 June 2015), 2013.

Sharma, R. K., Bhattarai, B. K., Sapkota, B. K., Gewali, M. B., and Kjeldstad, B.: Black carbon aerosols variation in Kathmandu valley, Nepal. Atmos. Environ., 63, 282-288, 2012.

Shindell, D., Kuylenstierna, J. C., Vignati, E., van Dingenen, R., Amann, M., Klimont, Z., Anenberg, S. C., Muller, N., JanssensMaenhout, G., Raes, F., Schwartz, J., Faluvegi, G., Pozzoli, L., Kupiainen, K., Hoglund-Isaksson, L., Emberson, L., Streets, D., Ramanathan, V., Hicks, K., Oanh, N. T., Milly, G., Williams, M., Demkine, V., and Fowler, D.: Simultaneously mitigating nearterm climate change and improving human health and food security, Science, 335, 183-189, doi:10.1126/science.1210026, 2012.

Shiraiwa, M., Kondo, Y., Iwamoto, T., and Kita, K.: Amplification of Light Absorption of Black Carbon by Organic Coating, Aerosol Sci. Tech., 44, 46-54, doi:10.1080/02786820903357686, 2010.

Skamarock, W. C., Klemp, J. B., Dudhia, J., Gill, D. O., Barker, D. M., Duda, M. G., Huang, X.-Y., Wang, W., and Powers, J. G.: A description of the Advanced Research WRF version 3, Mesoscale and Microscale Meteorology Division, National Center for Atmospheric Research, Boulder, CO, USA, 2008.

Smith, K. R., Jerrett, M., Anderson, H. R., Burnett, R. T., Stone, V., Derwent, R., Atkinson, R. W., Cohen, A., Shonkoff, S. B., Krewski, D., Pope, C. A., Thun, M. J., and Thurston, G.: Public health benefits of strategies to reduce greenhouse-gas emissions: health implications of short-lived greenhouse pollutants, The Lancet, 374, 2091-2103, doi:10.1016/s0140-6736(09)61716-5, 2009.

Solmon, F., Giorgi, F., and Liousse, C.: Aerosol modelling for regional climate studies: application to anthropogenic particles and evaluation over a European/African domain, Tellus B, 58, 51-72, doi:10.1111/j.1600-0889.2005.00155.x, 2006.

Swap, R. J., Annegarn, H. J., Suttles, J. T., King, M. D., Platnick, S., Privette, J. L., and Scholes, R. J.: Africa burning: A thematic analysis of the Southern African Regional Science Initiative (SAFARI 2000), J. Geophys. Res., 108, 8465, doi:10.1029/2003jd003747, 2003.

Tiitta, P., Vakkari, V., Croteau, P., Beukes, J. P., van Zyl, P. G., Josipovic, M., Venter, A. D., Jaars, K., Pienaar, J. J., Ng, N. L., Canagaratna, M. R., Jayne, J. T., Kerminen, V.-M., Kokkola, H., Kulmala, M., Laaksonen, A., Worsnop, D. R., and Laakso, L.: Chemical composition, main sources and temporal variability of $\mathrm{PM}_{1}$ aerosols in southern African grassland, Atmos. Chem. Phys., 14, 1909-1927, doi:10.5194/acp-14-1909-2014, 2014.

Tuccella, P., Curci, G., Visconti, G., Bessagnet, B., Menut, L., and Park, R. J.: Modelling of gas and aerosol with WRF-Chem over Europe: evaluation and sensitivity study, J. Geophys. Res., 117, D03303, doi:10.1029/2011JD016302, 2012.

Tummon, F., Solmon, F., Liousse, C., and Tadross, M.: Simulation of the direct and semidirect aerosol effects on the southern Africa regional climate during the biomass burning season, J. Geophys. Res., 115, D19206, doi:10.1029/2009jd013738, 2010.

Tyson, P. D. and Preston-Whyte, R. A.: The Weather and Climate of Southern Africa, Oxford University Press Southern Africa, Cape Town, 2000.

Vakkari, V., Laakso, H., Kulmala, M., Laaksonen, A., Mabaso, D., Molefe, M., Kgabi, N., and Laakso, L.: New particle formation events in semi-clean South African savannah, Atmos. Chem. Phys., 11, 3333-3346, doi:10.5194/acp-11-3333-2011, 2011.

Vakkari, V., Beukes, J. P., Laakso, H., Mabaso, D., Pienaar, J. J., Kulmala, M., and Laakso, L.: Long-term observations of aerosol size distributions in semi-clean and polluted savannah in South Africa, Atmos. Chem. Phys., 13, 1751-1770, doi:10.5194/acp13-1751-2013, 2013.

Vakkari, V., Kerminen, V.-M., Beukes, J. P., Tiitta, P., van Zyl, P. G., Josipovic, M., Venter, A. D., Jaars, K., Worsnop, D. R., Kulmala, M., and Laakso, L.: Rapid changes in biomass burning aerosols by atmospheric oxidation, Geophys. Res. Lett., 41, 2644-2651, doi:10.1002/2014g1059396, 2014.

Venter, A. D., Vakkar, V., Beukes, J. P., Van Zyl, P. G., Laakso, H., Mabaso, D., Tiitta, P., Josipovic, M., Kulmala, M., Pienaar, J. J., and Laakso, L.: An air quality assessment in the industrialised western Bushveld Igneous Complex, South Africa, S. Afr. J. Sci., 108, 1059, doi:10.4102/sajs.v108i9/10.1059, 2012.

Wang, Q., Huang, R. J., Cao, J., Han, Y., Wang, G., Li, G., Wang, Y., Dai, W., Zhang, R., and Zhou, Y.: Mixing State of Black Carbon Aerosol in a Heavily Polluted Urban Area of China: Implications for Light Absorption Enhancement, Aerosol Sci. Tech., 48, 689697, doi:10.1080/02786826.2014.917758, 2014.

Wiedinmyer, C., Akagi, S. K., Yokelson, R. J., Emmons, L. K., AlSaadi, J. A., Orlando, J. J., and Soja, A. J.: The Fire INventory from NCAR (FINN): a high resolution global model to estimate the emissions from open burning, Geosci. Model Dev., 4, 625641, doi:10.5194/gmd-4-625-2011, 2011.

Zeng, X. and Beljaars, A.: A prognostic scheme of sea surface skin temperature for modeling and data assimilation, Geophys. Res. Lett., 32, L14605, doi:10.1029/2005gl023030, 2005. 